\title{
Mites and ticks (Acari) Chapter 7.4
}

\author{
Maria Navajas', Alain Migeon', Agustin Estrada-Peña², \\ Anne-Catherine Mailleux ${ }^{3}$, Pablo Servigne ${ }^{4}$, Radmila Petanović ${ }^{5}$
}

I Institut National de la Recherche Agronomique, UMR CBGP (INRA/IRD/Cirad/Montpellier SupAgro), Campus International de Baillarguet, CS 30016, F-34988 Montferrier sur Lez, cedex, France 2 Faculty of Veterinary Medicine, Department of Parasitology, Miguel Servet 177, 50013-Zaragoza, Spain 3 Université catholique de Louvain, Unité d'écologie et de biogéographie, local B165.10, Croix du Sud, 4-5 (Bâtiment Carnoy), B-1348 Louvain-La-Neuve, Belgium 4 Service d'Ecologie Sociale, Université libre de Bruxelles, CP231, Avenue F. D. Roosevelt, 50, B-1050 Brussels, Belgium 5 Department of Entomology and Agricultural Zoology, Faculty of Agriculture University of Belgrade, Nemanjina 6, Belgrade-Zemun,11080 Serbia

Corresponding author: Maria Navajas (navajas@supagro.inra.fr)

Academic editor: David Roy | Received 4 February 2010 | Accepted 21 May 2010 | Published 6 July 2010

Citation: Navajas M et al. (2010) Mites and ticks (Acari). Chapter 7.4. In: Roques A et al. (Eds) Arthropod invasions in Europe. BioRisk 4(1): 149-192. doi: 10.3897/biorisk.4.58

\begin{abstract}
The inventory of the alien Acari of Europe includes 96 species alien to Europe and 5 cryptogenic species. Among the alien species, 87 are mites and 9 tick species. Besides ticks which are obligate ectoparasites, 14 mite species belong to the parasitic/predator regime. Among these species, some invaded Europe with rodents ( $8 \mathrm{spp}$.) and others are parasitic to birds ( $2 \mathrm{spp})$. The remaining 77 mite species are all phytophagous and among these $40 \%$ belong to the Eriophyidae ( 37 spp.) and $29 \%$ to the Tetranychidae ( 27 spp.) families. These two families include the most significant agricultural pest. The rate of introductions has exponentially increased within the $20^{\text {th }}$ century, the amplification of plant trade and agricultural commodities movements being the major invasion pathways. Most of the alien mite species (52\%) are from North America, Asia (25\%), and Central and South America (10\%). Half of the ticks (4 spp.) alien to Europe originated from Africa. Most of the mite species are inconspicuous and data regarding invasive species and distribution range is only partially available. More research is needed for a better understanding of the ecological and economic effects of introduced Acari.
\end{abstract}

\section{Keywords}

Europe, alien, mite, tick, Acari, Eriophyidae, Tetranychidae, biological control, Tetranychus evansi, Oligonychus perseae, Polyphagotarsonemus latus, Brevipalpus californicus, Aceria sheldoni, Aculops pelekassi, Dermatophagoides evansi, Varroa destructor

Copyright M. Navajas et al. This is an open access article distributed under the terms of the Creative Commons Attribution License, which permits unrestricted use, distribution, and reproduction in any medium, provided the original author and source are credited. 


\subsection{Introduction}

The subclass Acari, which includes mites and ticks, forms an important part of the class Arachnida, with a worldwide distribution and with over 55,000 (Krantz and Walter 2009) species described to date. An estimate of up to half a million to a million more species await discovery (Krantz and Walter 2009). Mites and ticks are a very diverse group ranging in size from about $0.08 \mathrm{~mm}$ up to 1 centimetre long. Acari differ from others Arachnida by the fusion of the abdominal segments as in Araneae (spiders) and from spiders by the presence of a gnathosoma containing mouthparts, the fusion of the posterior part of the prosoma (the podosoma, bearing legs) and fusion of an opisthosoma into an idiosoma (Evans et al. 1996). Most species are free living and have different trophic modes, including phytophagous, predators feeding on a variety of small invertebrates, fungivores and detritivores. Some species have developed complex parasitic relationships with both vertebrate and invertebrate animals. A number of acarine groups are injurious to crops and to livestock, both because of their feeding activities and because of their capacity as vectors for a variety of disease organisms to their plant or animal host. While the Oribatida is an important group (more than 6,000 species) having a key role in soil equilibrium, data regarding invasive species and distribution range remain largely unavailable. Ticks are very peculiar acarines, since they are obligate ectoparasites. In this sense they form a very homogenous group, with the order Ixodida composed of only three families. In this chapter, the two groups of Acari, mites and ticks, will be treated separately. The ticks will be presented through the description of a few significant case studies. By contrast, mites being much diversified in their biology and habitat use, and being truly ubiquitous, will be presented systematically.

Mites have successfully colonized nearly every known terrestrial, marine, and freshwater habitat. The most studied and observed invaders are found among the phytophagous mites of the families Tetranychidae and Eriophyidae, which include important agricultural pests. There is a growing awareness of the economic relevance of eriophyids as crop pests, including their importance as vectors of plant viruses, their role as alternative food for predators of plant pests, and their potential as weed control agents (Sabelis and Bruin 1996). A description on spider mite biology and their control is presented in the extensive review by Helle and Sabelis (1985). In addition to plantfeeding mites, a second group includes the alien parasitic mites. Among them, some invaded Europe with rodents such as muskrats (six alien species of mites), and brown rats (two aliens), while others are bird parasites (two species). Dermatophagoides evansi (Pyroglyphidae) is not associated with rodents and it has probably been accidentally introduced by humans (Bigliocchi and Maroli 1995,Hughes 1976, Thind and Clarke 2001). A single species in the family Varroidae, Varroa destructor, is alien to Europe (De Rycke et al. 2002, Griffiths and Bowman 1981).

Ticks are important parasites of livestock, wild animals, and humans. After their parasitic phase, they spend most of their life cycle outside their hosts, where prevailing climate conditions may constrain their ability to colonize a given territory. While 
some tick species are highly restricted to particular combinations of climatic variables, or have defined host species, others may occur in widely variable climate conditions and have catholic feeding habits. Some species of ticks can be considered as invasive species, since the uncontrolled movements of domestic animals may introduce alien species into Europe or disperse some species outside their native distribution ranges. The introduction via large-bodied host vectors (such as passerine birds) and the uncontrolled importation of reptiles, are important means for colonizing newly available areas. Furthermore, one species of tick, Rhipicephalus sanguineus, is spreading in parts of Europe out of its current range because of the movements of domestic dogs.

\subsubsection{Taxonomy of the mite species alien to Europe}

A total of 101 mite species have been considered as alien to Europe, including 96 species shown to have originated from other continents and 5 cryptogenic species (Table 7.4.1). These species involve 16 different families of mites (Figure 7.4.1). In addition, Table 7.4.2 provides some examples of mite species alien in Europe; i.e., European species introduced from one part of Europe to another where they are not native.

Alien mites belong to two super orders, Acariformes (Actinotrichida) and Parasitiformes (Anactinotrichida). Most of these species belong to two orders of Acariformes, Prostigmata and Astigmata. Prostigmata includes the three most important superfamilies:

* Tetranychoidea comprises two main families containing alien mites. The Tetranychidae family, or spider mites, includes 1,250 described species (http://www1. montpellier.inra.fr/CBGP/spmweb/). Among them, 100 can be considered as pests and 10 as major pests of agricultural crops. All stages are phytophagous and feed on parenchyma cells. No viruses associated with spider mites have been observed. The most widely distributed species is the highly polyphagous and ubiquitous Tetranychus urticae (two spotted spider mite), found on nearly 1,000 plant species. In Europe, alien spider mites are generally more specialized and occur on a single genus or family of plants. Due to their minute size (200 to $900 \mu \mathrm{m}$ ) typical of many species of Acari, spider mites remain undetected until major plant damage occurs. The members of another family, Tenuipalpidae, or false spider mites, are important obligate phytophagous mites. They are elongate, dorsoventrally flattened and usually have a reddish colour.

* Eriophyoidea includes three families:

- Eriophyidae, to which belong ca. 88\% of all known Eriophyoidea in the fauna of Europe (Fauna Europaea 2009). These are vermiform, four legged mites. The family includes important economic pests of broadleaved plants. All known mite vectors of plant pathogens and nearly all gall-forming species belong to this family. About half are vagrants. Most of the species in the genera Aceria and Eriophyes cause specific galls on the leaves, green twig, flower buds, vegetative buds, or fruit of the hosts (Oldfield 1996). Others, especially Epitrimerus, Phyllocoptes, Aculops and Aculus cause discolouration and other non-distortive damage to their hosts. 

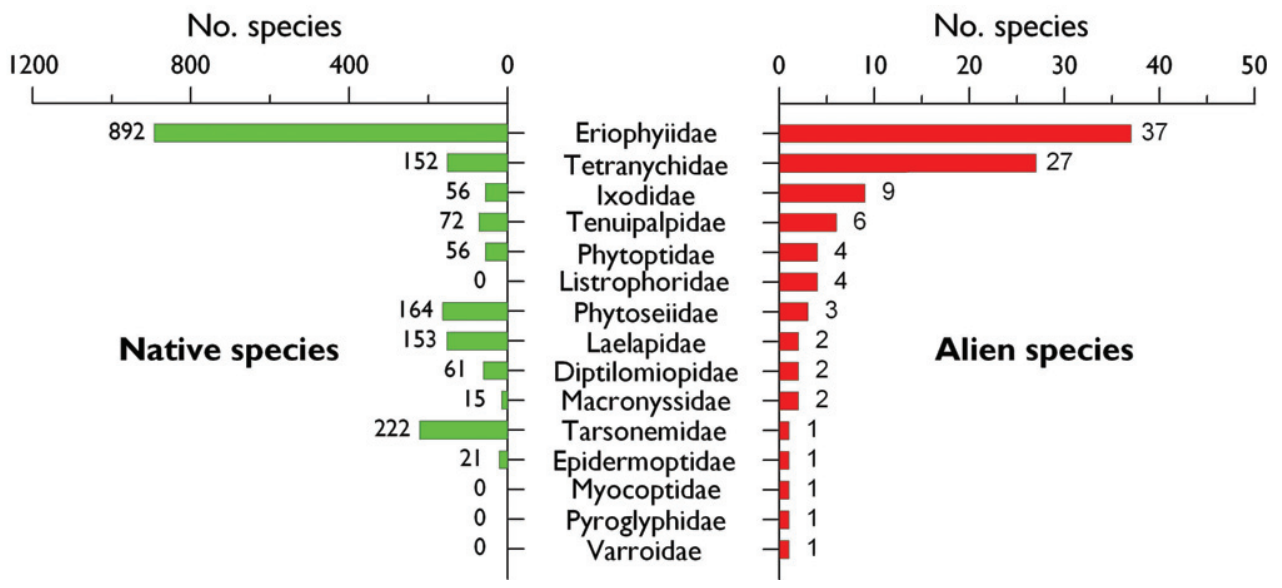

Figure 7.4.I. Relative importance of the mite families in the alien and native fauna in Europe. Families are presented in a decreasing order based on the number of alien species. Species alien to Europe include cryptogenic species. Only the most important families of native species (> $50 \mathrm{spp}$.) have been considered. The number over each bar indicates the number of species observed per family.

- Phytoptidae, which are obligate phytophagous and gall mites, with a high degree of specificity. They are also vermiform and four-legged. The family Phytoptidae is well represented on conifers (half of the described phytoptid species) and monocots. Phytoptidae is less represented than Eriophyidae or Diptilomiopidae on dicotyledons. Four alien species out of a total of 56 species have been reported in the fauna of Europe.

- Diptilomiopidae, which are predominantly leaf vagrants, only inhabiting leaves of dicotyledons, and rarely causing notable damage to their hosts (Keifer 1975). Two monotypic genera are known from only two families of monocotyledons (Poaceae and Palmae) occurring in the tropics. Rhyncaphytoptus species are mainly represented on several families of deciduous trees in the Holarctic region. Two alien species have been reported, out of the total 61 in the European fauna.

* Tarsonemoidea represented by the family Tarsonemidae includes economically important mites. Most of them are mycophagous. Some species are phytophagous, whereas others are parasites of bark beetle eggs, or predators of tetranychid eggs. The most redoubtable pest species in the family is the broad mite, Polyphagotarsonemus latus (=Hemitarsonemus latus), which was described in 1890 and has recently been redefined and considered as being a species complex (Gerson 1992).

The order Astigmata is less represented in the alien fauna. A few species belong to the super-family Sarcoptoidea, and especially to families Listrophoridae and Myocopidae. Members of Listrophoridae are usually small, elongate mites and are skin or hair parasites of mammals. The palpae and/or legs I-II are often highly modified for grasping hairs. Four species of Listrophoridae mites have invaded Europe, grasped to the fur of muskrats: Listrophorus americanus, L. dozieri, L. faini and L. validus (Šefrová and Laštůvka 2005). Myocopids, or hair mites, live on skin of marsupial and rodents (Bauer and Whitaker 1981, Šefrová and Laštůvka 2005, 
Whitaker 2007). Myocoptes ondatrae is an ectoparasite that has invaded Europe by grasping the fur of muskrats (Bauer and Whitaker 1981, Šefrová and Laštůvka 2005, Whitaker 2007). Other species belong to the super-family Acaroidea and families Epidermoptidae and Pyroglyphidae. Epidermoptidae are skin parasites of birds. Epidermoptes bilobatus causes avian scabies. Pyroglyphidae are external parasites living on bird feathers or are nidicolous. Dermatophagoides evansi feeds on human detritus, and lives in house dust as well as within bird nests (Piotrowski 1990, Razowski 1997).

Among the super-order Parasitiformes (Anactinotrichida), aliens belong to orders Ixodida and Mesostigmata. Ixodida is represented by the species in the family Ixodidae, which is treated in a separate section at the end of the chapter. Alien Mesostigmata belong to superfamilies Ascoidea and Dermanyssoidea. The first superfamily is represented by a single family with aliens, Phytoseiidae, which are predators of spider mites. In Europe, species such as Phytoseiulus persimilis, Amblyseius (Neoseiulus) californicus and Iphesius (Amblyseius) degenerans are used as biological control agents against phytophagous pests (Bartlett 1992, Croft et al. 1998, Easterbrook 1996, EPPO 2002, Garcia Mari and Gonzalez-Zamora 1999, Helle and Sabelis 1985, McMurtry and Croft 1997). Three families of Dermanyssoidea contain alien species. Varroidae mites are ectoparasites of honeybees. Varroa destructor is at present the most important parasite of Apis mellifera (L.). Varroa feeds on the haemolymph of adult, larval and pupal bees. Laelapidae mites live in soil, are nidicoles or parasitize small mammals and insects. Ondatralaelaps multispinosus is an ectoparasite of muskrats (Šefrová and Laštůvka 2005). Laelaps echidninus is a common worldwide ectoparasite of spiny rats, wild brown rats and is occasionally found on the house mouse and cotton rat (Wharton and Hansell 1957). Macronyssidae mites are haematophagous, have a large dorsal shield, prominent chelicerae and inconspicuous body setae (Easterbrook et al. 2008). Ornithonyssus bacoti is a parasite of rats, living in rat nests and their surroundings (Cole et al. 2005, Easterbrook et al. 2008, Fan and Petit 1998, Whitaker 2007). Ornithonyssus bursa is a natural parasite of common birds including pigeons, starlings, sparrows, Indian mynahs, poultry, and some wild birds, such as the robin (Berggren 2005).

\subsubsection{Temporal trends of introduction in Europe of alien mite species}

The rate of arrival of alien mites in Europe is increasing exponentially (Figure 7.4.2). An average of 2.1 alien species was newly recorded per year in Europe during 2000 2007 whereas only half this number was recorded during the period 1950-1974 (1 species/year). However, large differences were found between families.

The first records for Europe of all alien Tetranychidae are extensively documented in this chapter. There are no records reported before 1950; however, only few taxonomists were specialized on the family before this date. Since the second half of the $20^{\text {th }}$ century, tetranychid species have been reported at an average rate of one new species every two years, with an acceleration of reports (one species per year) since 2000. 


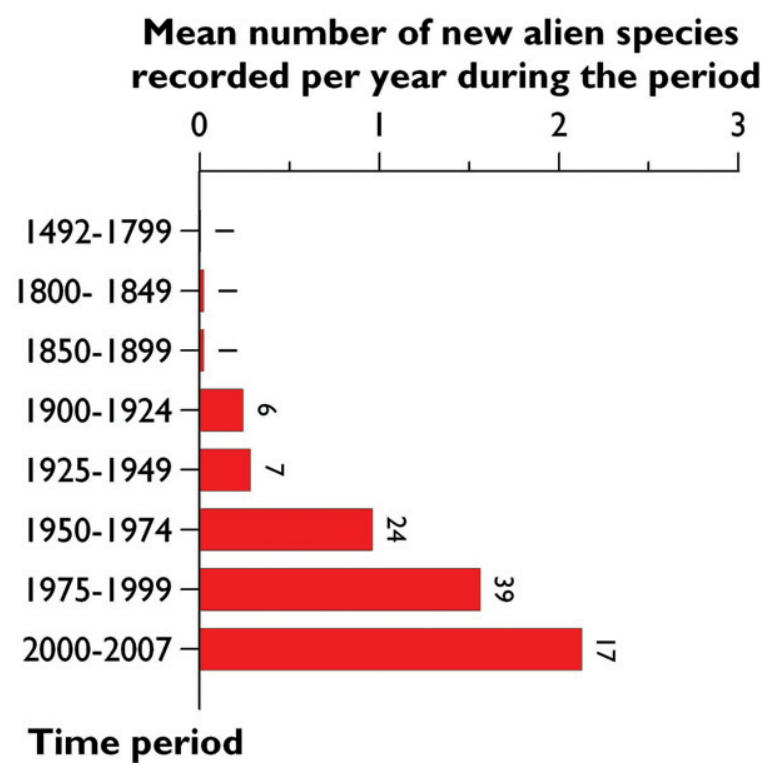

Figure 7.4.2. Temporal changes in the mean number of records per year of mite species alien to Europe from 1800 to 2009. The number over each bar indicates the absolute number of species newly recorded per time period.

Most of these mites represent agricultural pests, and therefore have been widely studied which explains the overrepresentation of crop pest species as Tetranychidae aliens.

The mean number of records of Eriophyoidae species alien to Europe increased rapidly during the third quarter of the $20^{\text {th }}$ century. Only one species Aceria alpestris, which is alien in Europe, was recorded within the period 1850-1899. This species was described from the host plant Rhododendron ferrugineum L. from Tirol (Austria). The species was later recorded in mainland Italy, Czech Republic, Slovenia and Serbia, but it is not clear if it was associated with cultivated Rhododendron. Species recorded intensively between 1900-1924 (although described from Germany in 1857) are categorized as cryptogenic (Eriophyes pyri, the pear blister mite) or alien in Europe, like Aculus hippocastani (recorded in 1907, but probably introduced in Europe from the $17^{\text {th }}$ century when its host plant Aesculus hippocastanum L. was intensively cultivated), and Aceria loewi (probably introduced in the $16^{\text {th }}$ century when lilac started to be cultivated in France). Aculops allotrichus, which is alien to Europe, was recorded in 1912 but was probably, introduced with its host Robinia pseudoacacia L. which was for the first time introduced into France at the beginning of $17^{\text {th }}$ century. Aceria erinea and A. tristriata were suspected to have an Asian origin and have been designated as aliens. They were recorded on 1903, but probably were present on its host, Persian walnut, in the Balkans and South Europe much earlier. Only one species in the Eriophyoidae was recorded between 1925-1949, e.g. Aceria petanovicae, the lilac rust mite. Being for long time known under the name of Aculops massalongoi the species is alien in Europe. 
Six alien species to Europe were recorded between 1950-1974. Two pests of citrus, Aceria sheldoni (citrus bud mite) and Aculops pelekassi (citrus rust mite) and the azalea mite Phyllocoptes azaleae, are suspected to have been introduced from Asia. Characteristic symptoms of deformed lemon fruits caused by $A$. sheldoni were drawn by Battista Ferrari in Italy in 1664 (Ragusa 2002). Three pests have been reported from North American maple trees (Acer negundo L., A. saccharinum L. and A. rubrum L.), i.e. Shevtchenkella brevisetosa, Vasates quadripedes and Rhyncaphytoptus negundivagrans. The 25 species recorded during the period 1975-1999 almost all have a North American origin (only Epitrimerus cupressi is designated as cryptogenic, because of the Mediterranean origin of its host Cupressus sempervirens L.). During the period from 2000 to 2007, one species alien to Europe, Rhyncaphytoptus bagdasariani, has been recorded as being introduced from Asia and the serious pest Aceria fuchsiae (a species on the European quarantine list) was introduced from South America. As for other phytophagous mites, the most probable explanation for the acceleration in the pace of introductions of alien eriophyids is intensification of international trade. Most of these alien species inhabit ornamental trees and shrubs, flowers and potted ornamental plants.

Some alien parasitic mites have invaded Europe with rodents such as muskrats and brown rats. The muskrat (Ondatra zibethicus L.) is an invasive rodent native to North America. It was introduced around 1905, by humans as a fur resource in several parts of Europe, as well as in Asia and South America. Six species of mites, native from North America (Bauer and Whitaker 1981, Whitaker 2007), have invaded Europe grasping its fur (Glavendekić et al. 2005, Šefrová and Laštůvka 2005). The first report of muskrat mites was recorded in 1955, and a second in 2000, both in Czech Republic. Two other parasitic species, Laelaps echidninus and Ornithonyssus bacoti, are also alien ectoparasites of rodents that have invaded Europe and were identified in the 1950's (Šefrová and Laštůvka 2005), but the exact pathway of introduction is not known. One possible vector is the wild brown rat, Rattus norvegicus (Berkenhout). Thought to have originated in northern China, this rodent spread in Europe in the middle ages and is now the dominant rat in the continent.

Birds are vectors of a second group of alien parasitic mites, that include Epidermoptes bilobatus and Ornithonyssus bursa, both identified in the 1950's, in the Czech Republic (Šefrová and Laštůvka 2005). The exact route of introduction is not known with confidence, but a possible vector is the chicken (Gallus gallus domesticus L.). In the $20^{\text {th }}$ century, with the intensifications of poultry production, concerns have been raised about the increasing risk of transfer of diseases and mites (from chickens to native bird species).

Whereas the exact date of arrival of alien mites is generally unknown, deliberately released biological control agents are the exception to this rule. Among them, three phytoseiids are mainly used as predatory species against pests (McMurtry and Croft 1997). Phytoseiulus persimilis was introduced for the first time in the 1970's in Bulgaria and Czech Republic (EPPO 2002, Šefrová and Laštůvka 2005). Neoseiulus californicus was introduced for the first time in 1991 in Great Britain (EPPO 2002). It was also introduced at the same period in the Czech Republic (EPPO 2002, Šefrová and Laštůvka 
2005). The third introduced mite is Iphiseius degenerans. It is native from the Mediterranean region and was introduced for the first time in 1993 in Czech Republic (EPPO 2002, Šefrová and Laštůvka 2005). Nowadays, these three biological agents have been introduced in most European countries.

\subsubsection{Biogeographic patterns of the mite species alien to Europe}

\subsubsection{Origin of the mite species alien to Europe}

Figure 7.4.3. presents the region of origin of the 101 alien species of mites. Most of the alien mite species (52\%) came from North America, then from Asia (25\%), and Central and South America (10\%). The origin of phytophagous alien mites can usually be inferred from the origin of the host plant. These mites are dispersed over long distances mainly by the introduction of plant material and spread further by plant cultivation in newly colonized regions. Aerial distribution is possible and most frequent, but mainly over short distances (Margolies 1993, Margolies 1995). In the case of highly polyphagous species such as several Tetranychidae, their ubiquity and highly diverse host uses might be misleading and the origin can be difficult to ascertain. Twelve out of 27 alien Tetranychidae originated in North America, nine in Asia and only five in Central and South America. Temperate regions provide the majority of the alien species (16 vs. 11 for tropical areas).

The majority of eriophyoid species are mono- or oligophagous and are distributed within the host range. North America appears to be the dominant source of the alien eriophyoid fauna with half of the species originating from this continent. Around $26 \%$ of species originate from Asia, and less than 10\% from South America. A few species are designated as cryptogenic or with questionable origin. For example, Rhyncaphytoptus negundivagrans, although described from Hungary, probably originated from North America with its host plant, Acer negundo. Whereas the camellia rust mite, Cosetacus cameliae (described from California) was probably introduced to Europe from the USA, it probably has an Asian origin considering that Camelia japonica L. comes from subtropical and tropical regions of Southeast Asia. The pouch gall mite of plum leaves, Eriophyes emarginatae, first discovered in the USA, has also been recorded in Serbia and Japan. This mite is very closely related to the European E. padi (Nalepa) (Petanović 1997) and may even be the same species, with synonymous names (Keifer 1975). Epitrimerus cupressi was described from North America, but according to the origin of its host plant Cupressus sempervirens, which is from the Mediterranean region, the mite probably has an European origin too. The gall mite Phytoptus hedericola (Phytoptidae) is native from South Africa (Glavendekić et al. 2005), and Trisetacus chamaecypari (Phytoptidae) from North America (Ostojá-starzewski and Halstead 2006, Smith et al. 2007).

Among the false spider mites (Tenuipalpidae), Brevipalpus californicus, B. obovatus and Tenuipalpus pacificus originated from Central and South America, and Florida 


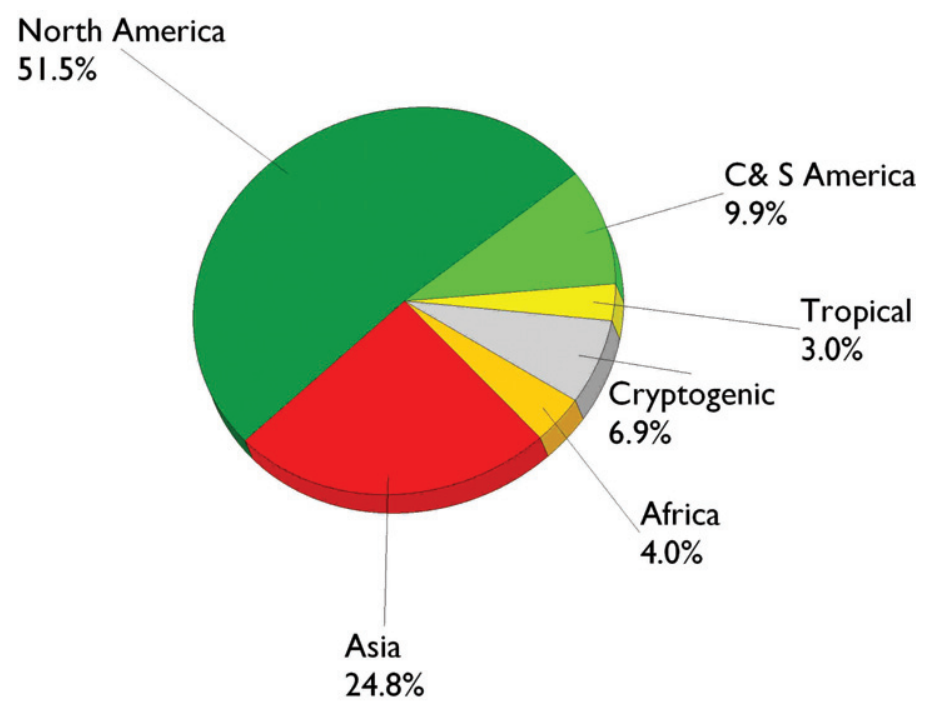

Figure 7.4.3. Origin of the mite species alien to Europe.

(USA) (Denmark 1968, Manson 1967). Six alien species of rodents bear parasitic mites originating from North America, and belong to the families Listophoridae (four species), Laelapidae (one species), and Myocoptidae (one species). In their native country, they are all ectoparasites of murskrats. There are also some bird parasites: one species of Epidermoptidae, Epidermoptes bilobatus, is an ectoparasite native from South Asia, and Ornithonyssus bursa is probably native from Trinidad.

A single Varroa species, $V$. destructor, is alien to Europe (Griffiths and Bowman 1981). Its native range is South East Asia, where it was originally confined on its original host, the Asian honeybee, Apis cerana F. This mite came to be a parasite of the European honeybee, Apis mellifera, in the mid-twentieth century. Importation of commercial $A$. mellifera colonies into areas with $A$. cerana brought the previously allopatric bee species into contact and allowed $V$. destructor to switch to the new host

\subsubsection{Distribution in Europe of the alien mite species}

Alien mite species are not evenly distributed throughout Europe. Large differences in the number of aliens are noticed between countries (Figure 7.4.4) but it may reflect differences in sampling efforts and in the number of local taxonomic specialists.

Among the Tetranychidae, 19 alien species are found around the Mediterranean Basin and 12 in the rest of Europe. With relatively warm winters, the Mediterranean region provides suitable climatic living conditions for many species of temperate climates, but also for the establishment of many species of tropical or sub-tropical origin. Except for Panonychus citri and the cryptic species Tetranychus ludeni, which can be found in glasshouses in Europe, all tropical alien spider mites are restricted to the area around the Mediterranean Sea. 


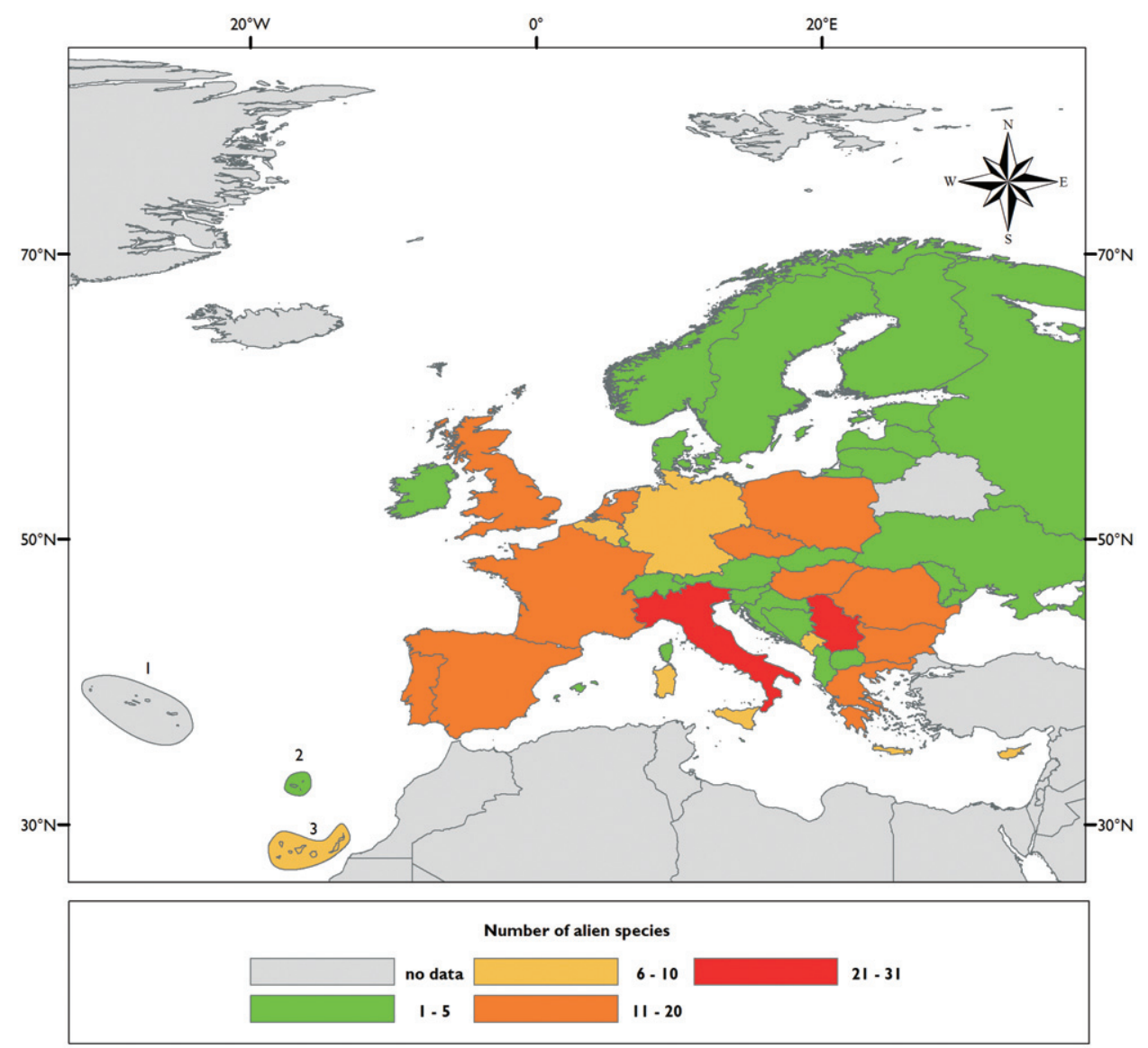

Figure 7.4.4. Comparative colonization of continental European countries and islands by mite species alien to Europe. Archipelago: I Azores $\mathbf{2}$ Madeira $\mathbf{3}$ Canary Islands.

Most alien Eriophyids have a very restricted distribution. More than $40 \%$ of the species have been observed in only one country (17 species), more than $40 \%$ (21 species) in $2-5$ countries, and approximately $20 \%$ (7 species) in 6-11 countries. Eight European countries have no recorded occurrence of alien eriophyoids to date. Only one species, the pear blister mite Eriophyes pyri (which has cryptogenic status), has been recorded from 32 European countries. Besides E. pyri, the more widely distributed eriophyoid species are: Aceria erinea, A. loewi, A. sheldoni, Aculops pelekassi and Eriophyes canestrini. The gall mite Phytoptus hedericola (Phytoptidae) entered Europe in 2002 and has been observed in Serbia (Glavendekić et al. 2005). Trisetacus chamaecypari (Phytoptidae) entered Europe in 2002 (Ostojá-starzewski and Halstead 2006, Smith et al. 2007). The status of Typhloctonus squamiger (Phytoseiidae), a poorly known phytophagous mite found on trees in Italy since 1991 (Rigamonti and Lozzia 1999), is questionable.

The distribution of biological agents belonging to the Phytoseiidae family is wellknown. Phytoseiulus persimilis is now present in nearly all of Europe (Table 7.4.1) 
(EPPO 2002). Neoseiulus californicus has been found in the same countries except Austria, Hungary, Morocco, Slovakia, Sweden and Turkey. The third introduced phytoseid mite, Iphesius degenerans, is also present in several countries (Table 7.4.1).

The broad mite Polyphagotarsonemus latus (Tarsonemidae) is now cosmopolitan. In Europe, it was reported for the first time in 1961 and since then the mite has invaded almost all countries (Table 7.4.1) (CAB-International 1986, Fan and Petit 1998, Natarajan 1988, Parker and Gerson 1994); it is potentially now in all parts of Europe.

Three species of false spider mites (Tenuipalpidae) are major invaders in Europe. Brevipalpus californicus, found in 316 orchid and tree species of 67 genera and 33 families, was first recorded in 1960 and is mainly observed in citrus trees around the Mediterranean basin (Denmark 1968, Manson 1967). The privet mite, Brevipalpus obovatus is found in 451 herb, ornamental and shrub species (19 genera, 55 families) (Manson 1967) has been recorded from Austria, Cyprus, France, Germany, Israel, Netherlands, Serbia and Spain (Manson 1967). Tenuipalpus pacificus (the Phalaenopsis mite) is found in greenhouses of Phalaenopsis orchids in Germany, Great Britain, Netherlands and Serbia (Denmark 1968, Manson 1967).

The introduced range of Varroa destructor is practically worldwide. It was first reported in Eastern Europe in the mid-1960s and it has spread rapidly all over the continent. Two different genotypes, characterized by mitochondrial DNA sequences, have spread as independent clonal populations (Solignac et al. 2005), the Korean and the Japanese haplotypes, the latter having been found, besides Asia, in the Americas only.

\subsubsection{Pathways of introduction in Europe of alien mite species}

Although colonisation routes are poorly documented for the Tetranychidae, it is known that many species travel with their host plant. Small organisms like tetranychids are easily transported with plant material (leaves and in bark crevices). Only five species feed mainly on herbaceous plants (Tetranychus evansi, T. macfarleni, T. sinhai, Schizotetranychus parasemus, and Petrobia lupini), whereas all other alien species in the family feed on perennial shrubs.

As for tetranychids, the horticultural and ornamental trade is probably the most important factor for accidental introductions of almost all species of alien Eriophyoidae. Just a few species of Eriophyoids are on European quarantine lists, as plants are rarely inspected for presence of these mites. Infested plant material is not regularly intercepted at borders even in the case of important pests such as the grape rust mite Calepitrimerus vitis (Nalepa) or the blackberry fruit mite Acalitus essigi (Hassan), which are frequently disseminated with plant seedlings. During recent decades more than $50 \%$ of aliens were imported with ornamental plants. Among eriophyids, which are obligate plant parasites, only one trophic group which is associated with weeds, can be subject to intentional introduction. Although these mites were recently nominated as potential agents for classical biological control of weeds (few species are imported for this purpose), they have not yet been used for this purpose in Europe. Four species of 
alien eriophyoids which were probably introduced along with their host plants may have the potential as biological control agents of serious alien weed pests. In particular, Aceria ambrosiae can be used against the allergenous weed Ambrosia artemisifolia L. that was imported into Europe from North America.

As for other phytophagous species, the broad mite Polyphagotarsonemus latus (Tarsonemidae) has mainly been dispersed by human activities, but also by wind or insect transfer. Movement by insects should not be neglected: this concerns almost only females that get attached to the legs of aphids and the whiteflies Bemisia argentifolii (Bellows and Perring), Bemisia tabaci (Gennadius) and Trialeurodes vaporariorum (Westwood) (Homoptera: Aleyrodidae) (Fan and Petit 1998, Natarajan 1988, Parker and Gerson 1994).

Although including important crop pest species, the dispersal potential of false spider mites (Brevipalpus spp.), Tenuipalpidae, remains unclear (Childers et al. 2003a, 2003b).

Intentional introductions of mites represent a low proportion of alien arrivals. Only three phytoseeid predators were introduced purposely for biological control and have established. Some of these biological control agents were released in the field but others were first released in glasshouses, and then escaped and became established outdoors.

International travel and commerce has facilitated the dispersal of Varroa destructor. Once established in a new region, the mite spreads using drifting, robbing, and swarming behaviour of the host. Human mediated varroa dispersion also occurs via apicultural practices.

\subsubsection{Ecosystems and habitats invaded in Europe by alien mite species}

Alien mites established in Europe predominantly live in agrosystems or anthropogenic environments (ca. 92\%; Figure 7.4.5). This is especially verified in Tetranychidae and Eriophyidae. Among eriophyoids, some are present in man-made habitats, parks and gardens (22 species), agricultural lands (13 species), and greenhouses (10 species); very few species inhabit woodland and forest, costal, alpine or sub alpine habitats. Most alien species in this superfamily are leaf vagrants (13 species). Twelve species cause leaf galls, erinea* and leaf rolling, 11 cause leaf and/or fruit russeting or other type of discolouration, six live predominantly in buds causing bud galls, three species cause stunting of whole plants and/or plant organs and two cause flower and/or fruit deformations. Among the leaf gall makers, the most important horticultural pests are distributed in many European countries, such as E. pyri, A. erinea, A. tristriata or, such as A. fuchsiae which is on quarantine lists. Among the rust mites, only a few are important horticultural pests like $A$. theae, A. pelekassi and C. carinatus. Most species are pests of ornamental trees, shrubs or flowering plants, having an important aesthetic impact on plants in parks and streets in most European towns and cities (i.e. A. gleditsiae, A.ligustri, A. petanovicae, S. strobicus, P. chrysanthemi), an exception being A. sawatch- 


\section{Percentage of alien mites living in the habitat}

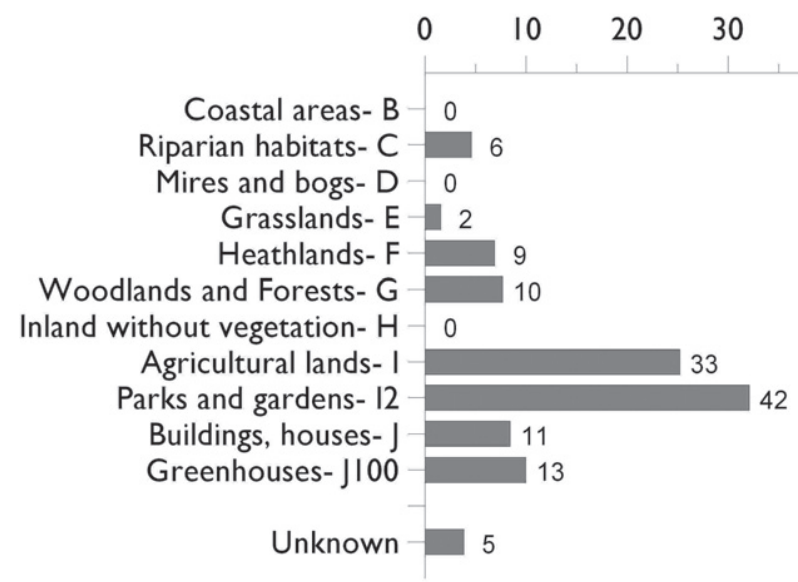

\section{Habitats}

Figure 7.4.5. Main European habitats colonized by the established alien species of mites. The number over each bar indicates the absolute number of alien dipterans recorded per habitat. Note that a species may have colonized several habitats.

ensae which inhabits weeds. Two Eriophyoids which cause plant stunting, $A$. paradianthi and T. califraxini, are important pests of ornamental plants and one species, $A$. ambrosiae, is a potential biocontrol agent against the alien weed Ambrosia artemisifolia. Two species which cause flower and/or fruit deformations, A. alpestris and A. sheldoni, are respectively pests of Rhododendron and citrus trees.

The gall mite Phytoptus hedericola lives on ivy (Hedera helix L.) and Trisetacus laricis switched from American larch to European larch (Larix decidua Mill.).

The broad mite Polyphagotarsonemus latus (Tarsonemidae) has a very short life cycle of a few days, damaging crops abruptly. Being highly polyphagous, the species has been reported on 57 plant families (Gerson 1992) both in open field crops and in greenhouses. This is an important pest of crops and ornamental plants such as azaleas, castor bean, chillies, citrus fruits, cotton, cucumber, mango, papaya, pepper, potato, sweet potato, tea, tomato and winged bean (Gerson 1992, Glavendekić et al. 2005, Heungens 1986, Raemaekers 2001). Nevertheless, in Europe this mite is found mainly in greenhouses because the mite cannot survive winter conditions outdoors.

False spider mites (Brevipalpus spp.; Tenuipalpidae) present a risk of invasion in greenhouses. Brevipalpus obovatus (the privet mite) is found on ornamentals and shrubs like citrus and azaleas and could become of great importance in glasshouses for ornamentals (Childers et al. 2003a, 2003b). Tenuipalpus pacificus (the Phalaenopsis mite) is one of the rare monophagous mites in the family, but it is a very destructive pest of orchids under greenhouses, mainly because it has several generations per year and has a two-month life cycle (Denmark 1968, Manson 1967). 
A Pyroglyphidae mite, Dermatophagoides evansi, is a cosmopolitan free-living species, often encountered in synanthropic situations and has probably been accidentally introduced by humans (Bigliocchi and Maroli 1995, Hughes 1976).

\subsubsection{Ecological and economic impact of alien mite species}

Seven species of alien Tetranychidae are important pests. On citrus, four alien species are found: Panonychus citri, Eotetranychus lewisi (also on grapes) Eutetranychus banksi and E. orientalis, the last presently spreading to Southern Portugal and Spain from Huelva to Murcia and Alicante. Oligonychus perseae is found on avocado and produces very severe damage in southern Spain (Malaga, Granada and Huelva) and in the Canary Islands. Stigmaeopsis celarius is found on bamboos and causes important visual damage to these ornamental plants. Tetranychus evansi is found on solanaceous crops and can reach very high density as observed in France, Spain and Canary Islands. All these mites are present in the Mediterranean Basin, which appears to be the region most threatened by alien species. Only two of these species can be found outside the Mediterranean area: Panonychus citri, especially in glass-houses, and Stigmaeopsis celarius.

In humid citrus-growing regions of the world, eriophyoid mites are considered to be the major mite pests (Jeppson et al. 1975, McCoy 1996). Two alien species, Aceria sheldoni and Aculops pelekassi, distributed worldwide, are among the most important pests infesting citrus. The pear blister mite, Eriophyes pyri, widely distributed in Europe, probably does little harm to the tree, but in severe infestations, the tree leaves may become disfigured, and most importantly the mite may damage fruits (Easterbrook et al. 2008). Besides fruit orchards, species in the superfamily inhabiting wild trees in natural forests are: Aceria tristriata and $A$. erinea which appear to be the most common and most injurious eriophyoids found on Juglans regia L. (Castagnoli and Oldfield 1996). Among the five species of eriophyoid mites reported from commercially important beverage crops in different parts of the world, wherever tea is grown, the purple tea mite Calacarus carinatus and the pink tea mite Acaphylla theae are economically important in Southeast Asian countries, and in India (Channabasavanna 1996). Both species are aliens to Europe, reported from mainland Italy (A. theae) and from Hungary, Poland and Spain (C. carinatus). Records concerning host plant range in the case of $C$. carinatus are, besides tea, Viburnum opulus L. and Capsicum annuum L. (Amrine and Stasny 1994). Bearing in mind that congeneric Calacarus citrifolii has an extremely wide host range (Oldfield 1996), this might be also the case for $C$. carinatus, which would convey on the latter serious pest status in Europe. Economic impact of alien pest species of eriophyoids on ornamentals has been observed for Aculops gleditsiae on honey locust, Aceria petanovicie on lilac, Aculops ligustri on privet hedges, Aculops allotrichus on black locust, Reckella celtis on Celtis australis L., Shevtchenkella brevisetosa on Acer negundo, Vasates quadripes on silver maple, Phytoptus hederae on English ivy, and Setoptus strobicus on Pinus strobus L. (Petanović 2004). Flower and foliage aesthetic impact has been observed indoors (business centers, restaurants, shopping centers, hotels, etc.) for a few alien eriophyoids, Cecidophyopsis hendersoni causing a powdery 


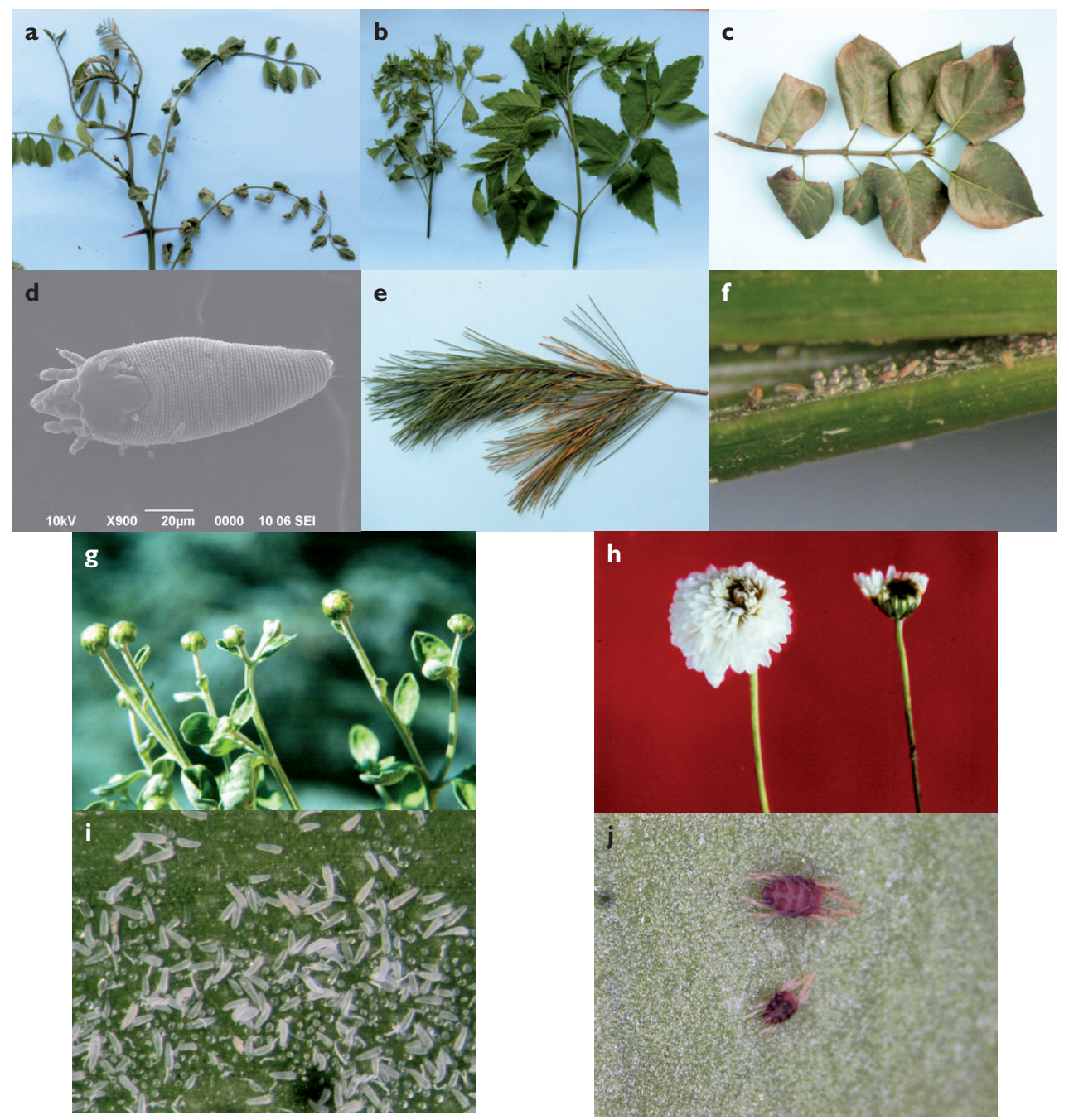

Figure 7.4.6. Alien mites and their damage. a Curling and rusting of black locust leaves caused by Aculops allotrichus $\mathbf{b}$ Chlorotic and misshapen leaves of Acer negundo caused by Shevtchenkella brevisetosa (left) and uninfested leaves (right) $\mathbf{c}$ Leaf rusting of lilac leaves caused by Aceria petanovicae $\mathbf{d}$ Aceria petanovicae, dorsal view-SEM photograph e Rusting of Pinus strobus needles caused by Setoptus strobacus $\mathbf{f}$ Setoptus strobacus eggs, juveniles and adults between needles of Pinus strobus $\mathbf{g}$ Leaf distortion and unopened damaged flower buds of chrysanthemum caused by Paraphytoptus chrysanthemi $\mathbf{h}$ Deformed flower heads of chrysanthemum caused by Paraphytoptus chrysanthemi i Colony of Cecidophyopsis hendersoni on Yucca leaf j Panonychus citri. (a-i Credit: Radmila Petanović; j Credit: Alain Migeon).

appearance on Yucca leaves, Cosetacus cameliae causing bud rust and abortion on flower buds of Camelia plants, and Paraphytoptus chrysanthemi causing deformed buds, hairy leaves and rust on Chrysanthemum (Petanović 2004).

The broad mite Polyphagotarsonemus latus (Tarsonemidae) and the false spider mites (Brevipalpus spp.) (Tenuipalpidae) are major pests of great agronomical impor- 
tance because of their broad host range, worldwide distribution and economic impact (CAB-International 1986, Fan and Petit 1998, Gerson 1992, Heungens 1986, Natarajan 1988, Parker and Gerson 1994, Raemaekers 2001). The most important threat for Brevipalpus spp. is the spread of citrus viruses (Childers et al. 2003b).

Among parasitic mites, the hair mites (muskrat mites) are currently considered non-pathogenic for humans although they are sometimes found in the fur of other mammals. Laelaps echidninus (Laelapidae) is a common worldwide ectoparasite of the spiny rats (hystricognath rodents), wild brown rat and is occasionally found on the house mouse, cotton rat and other rodents. It is a bloodsucking mite and the natural vector of Hepatozoon muris Balf. (Protozoa, Adeleidae), a haemogregarine parasite pathogenic for white rats (Smith et al. 2007) but which should not be overlooked as a possible vector of disease to humans (Wharton and Hansell 1957). Ornithonyssus bacoti (Macronyssidae) is a parasite of rats and inhabits the area in and around the rat's nesting area. This mite is the only one of the common rat mites which frequently deserts domestic rats to bite man or his domestic and laboratory animals (Cole et al. 2005). It is also a bloodsucking mite and its bite is painful and causes skin irritation, itching and skin dermatitis in humans (James 2005). Ornithonyssus bacoti, is a known vector of the murine filarial nematode Litomosoides carinii Travasaos. In addition, it is susceptible to the transmission of endemic typhus, Rickettsia typhi (Wolbach and Todd) 1943 (= R. mooseri Monteiro) to humans (Berggren 2005, Bowman et al. 2003).

Epidermoptes bilobatus (Epidermoptidae) is a bird parasite causing avian scabies. This endoparasite burrows into the skin causing inflammation and itchiness. The skin thickens with brownish-yellow scabs, which may become secondarily infected with a fungus. It is difficult to control and can cause death. Culling infested birds is usually required (Department of the Environment and Heritage 2006). Ornithonyssus bursa (Macronyssidae) is an haematophagous natural parasite of common birds including pigeons, starlings, sparrows, Indian mynahs, poultry, robin (Berggren 2005). These pest mites and parasites are and will remain a long term problem for poultry housing (Gjelstrup and Møller 1985). Although none of these two species of mites are truly parasitic on humans and pets, they readily bite humans and are liable to cause allergies and dermatitis in human (Denmark and Cromroy 2008, James 2005). Dermatophagoides evansi (Pyroglyphidae), and a species alien in Europe, Glycyphagus domesticus (Glycyphagidae), have been accidentally introduced by humans and often encountered in synanthropic situations (Bigliocchi and Maroli 1995, Hughes 1976, Thind and Clarke 2001). Glycyphagus domesticus also occurs in bird, bat and mammal nests. It is associated with moist and humid conditions that promote the growth of mould on which they feed (Thind and Clarke 2001). Dermatophagoides evansi (Pyroglyphidae) feeds on detritus and is also found in house dust, birds' nests and poultry houses (Piotrowski 1990, Razowski 1997). Dermatophagoides evansi represents a source of airborne allergens in indoor house dust (Eriksson 1990, Musken et al. 2000) that may cause sensitization, dermatitis, rhinopharyngitis and asthma especially among farmers.

The honeybee ectoparasite Varroa destructor causes serious losses through feeding injury in apiaries in Europe but also almost worldwide. While the populations of the 

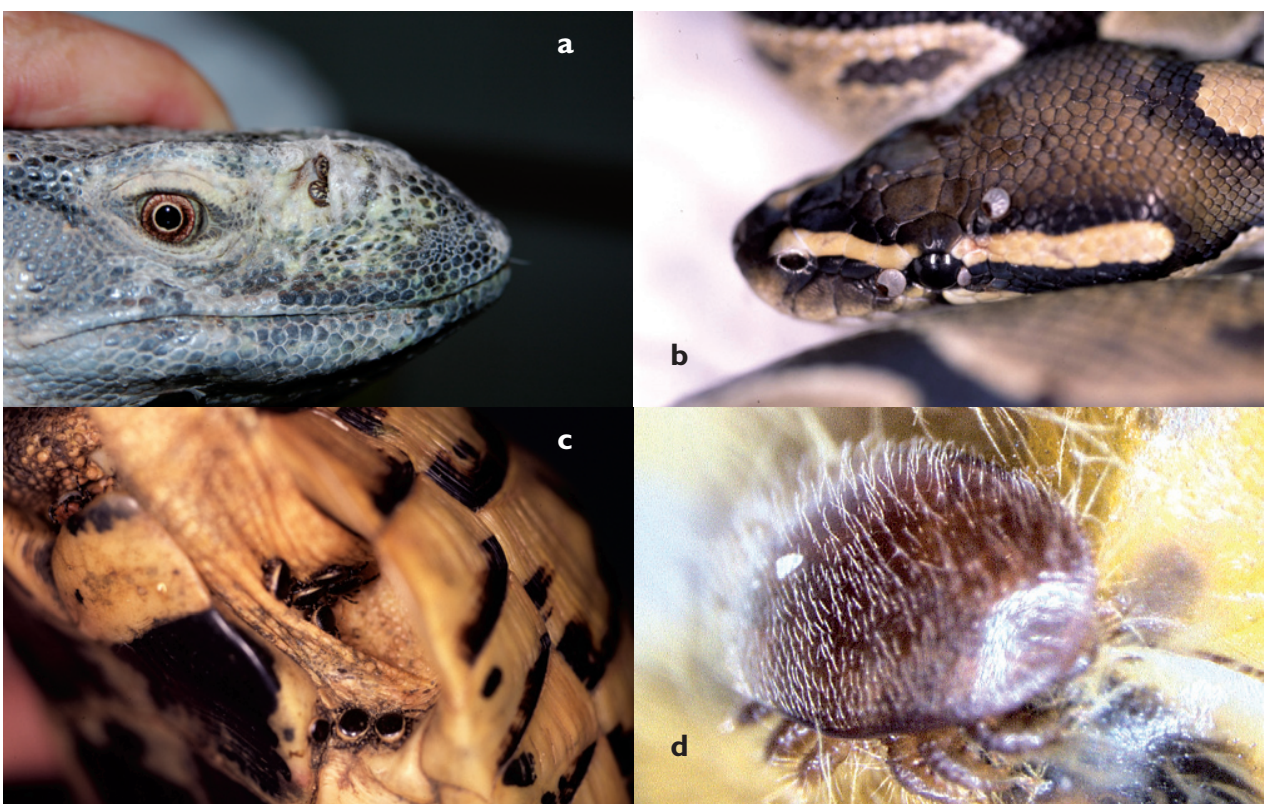

Figure 7.4.7. Ixodidae ticks on tortoises and snakes. a Hyalomma aegyptium on tortoise $\mathbf{b}$ Amblyomma exornatum semi-engorged on Python head c Amblyomma sp. on snake head (Credits: Nicasio Brotons) d Female of Varroa destructor on abdomen of Apis mellifera (Credit: Alain Migeon).

parasite reach only a small size within colonies of $A$. cerana and do not damage the colony, infested $A$. mellifera colonies die. The problems with varroa control are typical of those encountered in curbing arthropod pest population. Varroas are becoming resistant to the acaricides used by beekeepers to control them. The recent discovery in several parts of the world (notably the United States of America (Harbo and Harris 2005) and Europe (Le Conte et al. 2007)) of honeybee bee colonies able to tolerate heavy infestations of $V$. destructor opens the door to lasting solutions for controlling the parasite.

A positive impact is recognized for the three mite species deliberately introduced to Europe for biological control of house flies and tetranychid mites. Phytoseiulus persimilis and $N$. californicus are two well-known biological control agents used against spiders mites such as Tetranychus urticae Koch (Garcia Mari and Gonzalez-Zamora 1999, Helle and Sabelis 1985) and Phytonemus pallidus (Banks) (James 2005). The third introduced mite, Iphiseius degenerans, targets numerous species of thrips (van Houten and van Stratum 1993, van Houten and van Stratum 1995), e.g. Thrips tabaci Lindeman and Frankliniella occidentalis (Pergande) (Albajes et al. 1999, Bartlett 1992, McMurtry and Croft 1997, Sengonca et al. 2004).

\subsubsection{Alien tick species: case studies}

It is difficult to ascertain if a tick may have permanent populations outside of its native range or, to the contrary, they are just isolated records. In some cases, a few examples 
of a given species have been reported for a small area or found over non-resident hosts. This may result from the introduction of a few specimens, commonly immature stages. The most important means of introduction and expansion of ticks (provided that suitable climate and host is available) is by means of engorged females, because of their huge potential to lay thousands of eggs.

The movements of domestic ungulates have introduced some tick species, that may be considered to produce permanent and viable populations out of their native range. An example is the introduction of Hyalomma dromedarii into the Canary Islands, by the importation of dromedaries (Camelus bactrianus L.). The native range of this tick is northern Africa where C. bactrianus is the main adult host, and H. dromedarii is abundant in wide areas of Mauritania and Morocco. The current population of dromedaries in the Canary Islands was introduced from Morocco at the end of $18^{\text {th }}$ Century, and it seems that this tick came into these islands using dromedary hosts. H. dromedarii may use a wide range of hosts in immature stages, thus increasing risk of spread and permanent establishment (Apanaskevich and Horak 2008, Apanaskevich et al. 2008). It is difficult, however, to assess the reliability of records of Hyalomma anatolicum excavatum. A recent review of the original two subspecies ( $H$. a. anatolicum and $H$. a. excavatum), concluded that they should be considered as separate species, although the matter is hard to decide as both taxa have a well defined allopatric range (Apanaskevich 2003). $H$. excavatum is restricted to central and eastern Asia and $H$. anatolicum colonizes wide areas of northern Africa. The records of H. excavatum from Bulgaria, Albania, Greece, and Italy should be cautiously treated, as they may probably represent $H$. anatolicum imported from northern Africa with domestic ungulates, as is the case for Hyalomma detritum. The formerly recognized species $H$. detritum, restricted to northern Africa, is now considered to be a synonym of the European $H$. scupense, which occurs not only in scattered localities of mainland Europe but is present in wide areas of northern Africa. Similarly, caution should be also applied for the single record of Hyalomma truncatum in the Canary islands. This tick is currently known to be restricted to parts of Asia, while a close species, $H$. rufipes, is common in sub-saharan Africa. While the adults of $H$. rufipes feed on a variety of hosts, including domestic ungulates, the immature stages commonly attach to diverse passerine birds. Most of these birds perform long distance travel in their migratory flights from Africa to Europe, and they have been found carrying hundreds of immature ticks (Hoogstraal 1956). However, as mentioned above, it is difficult for a population of nymphs to produce a viable and permanent population of resident ticks. To our knowledge, H. rufipes has been recorded only in Cyprus and Macedonia (Apanaskevich and Horak 2008), and we still do not know if these are permanent populations or only accidental records on their passerine hosts on migration to lower latitudes from sub-saharan Africa.

The scenario for the tortoise tick, Hyalomma aegyptium, is however different. Its presence outside northern Africa has been reported in countries such as Romania, Spain, Italy, Greece, Bulgaria, Croatia, and even farther north in Belgium (Siroky Pet al. 2007). The tick has permanent populations in areas of southern Russia (Robbins et al. 1998). There have been also introductions of this tick by tortoises imported form 
northern Africa or eastern Europe, where this tick is common. The only record of a permanent population of $H$. aegyptium as a consequence of an accidental importation recorded for eastern Spain (Brotóns and Estrada-Peña 2004). Since the ticks attach to portions of the neck and legs of the host body, it may be difficult to find feeding stages even after careful observation of the hosts. In the reported case of introduction of several specimens of Testudo graeca infested by ticks, the hosts were kept in a large private garden with a Mediterranean-type climate and vegetation. After some years of recurrent tick parasitism in the tortoises without new importations and repeated treatments, it was realized that the tick had permanent populations in the garden, and the hosts became infested according to the seasonal activity of the ticks.

An interesting case of tick introduction into mainland Europa are ticks commonly found on snakes, like Amblyomma latum and A. exornatum (both formerly in the genus Aponomma). These ticks feed for a long period on the host, and owing to their small size and preference to feed under host scales, they are commonly unrecognized while importing a host out of its native range. Amblyomma latum is a very common parasite of Python spp., which is becoming increasingly popular as a pet in Europe. The only known case of an importation of $A$. exornatum was noticed on specimens of Varanus niloticus that arrived into Spain (Estrada-Peña (Unpubl.)). These imported ticks founded a permanent population in the terrarium where the lizards live, under suitable conditions of high relative humidity and controlled temperature.

A very peculiar case of tick introduction is an alien in Europe, the brown dog tick, Rhipicephalus sanguineus. While feeding on domestic dogs, this tick is endophilic and is normally restricted to the Mediterranean region, being abundant in kennels, human constructions and private gardens where dogs remain unprotected against tick bites. Because of its endophilic behaviour, this tick may survive independently of prevailing environmental conditions, since human habitations buffer harsh climate. Therefore, unprotected pets travelling may harbor feeding ticks, and introduce them to uninfested areas which might be far from their native range. Such cases of introduction have been commonly recorded in the United Kingdom and northern European countries (Garben et al. 1980, Sibomana et al. 1986), as well as in Czech Republic (Černý 1985). Although there are as yet no reports of its establishment outdoors, this tick could become established out of its former native range as a consequence of global warming.

\section{References}

Albajes R, Gullino ML, van Lenteren JC, Elad Y (1999) Biological control of thrips. In: Integrated Pest and Disease Management in Greenhouse Crops. The Netherlands: Springer. pp. 244-253.

Alcázar MD, Aranda G, Márquez AL, Sánchez L, Ruiz C (2005) Oligonychus persea (Acari: Tetranychidae); una nueva plaga en el aguacate en el Sur de Espańa. IV Congresso Nacional de Entomología Aplicada - X Jornadas Científicas de la SEEA - I Jornadas Portuguesas de Entomologia Aplicada, Bragança - Portugal: 213. 
Amrine JW Jr, Stasny TAH (1994) Catalog of the Eriophyoidea (Acarina, Prostigmata) of the World. West Bloomfield, Michigan: Indira Publishing House. 531 pp.

Anagnou-Veroniki M, Papaioannou-Souliotes P, Karanastasi E, Giannopolitis CN (2008) New records of plant pests and weeds. Hellenic Plant Protection journal, 1: 55-78.

Apanaskevich DA (2003) Differentiation of closely related species Hyalomma anatolicum and H. excavatum (Acari, Ixodidae) based on a study of all life cycle stages, throughout their entire geographical range. Parazitologiya 37: 259-280.

Apanaskevich DA, Horak IG (2008) The genus Hyalomma Koch, 1844: V. Re-evaluation of the taxonomic rank of taxa comprising the $H$. (Euhyalomma) marginatum Koch complex of species (Acari: Ixodidae) with redescription of all parasitic stages and notes on biology. International Journal of Acarology 34: 13-42.

Apanaskevich DA, Santos-Silva M, Horak I (2008) The genus Hyalomma, Koch 1844. IV. Redescription of all parasitic stages of $H$. (Euhyalomma) lusitanicum Koch, 1844 and the adults of $H$. (E.) franchinnii Tonelli Rondelli, 1932 (Acari: Ixodidae) with a first description of its immature stages. Folia Parasitologica 55: 61-74.

Aucejo S, Foo M, Gimeno E, Gomez-Cadenas A, Monfort R, Obiol F, Prades E, Ramis M, Ripolles JL, Tirado V, Zaragoza L, Jacas JA, Martinez-Ferrer MT (2003) Management of Tetranychus urticae in citrus in Spain: acarofauna associated to weeds. Bulletin OILB/SROP 26: 213-220.

Auger P, Migeon A (2007) Les tétranyques des bambous en France. PHM Revue Horticole 488: 17-19.

Balevski A (1967) [Tetranychid mites occuring on fruit crops] (in Bulgarian). Izvestija na Instituta za Zastita na Rastenijata, Gara Kostinbrod: 157.

Bartlett PW (1992) Experience of polyphagous pests of protected crops in Great Britain. EPPO Bulletin 22: 337-346.

Battelli C, Catteruccia G, Sobrero L (1977) Hyalomma excavatum Koch in Italia. Atti Societá italiana di Scienze veterinarie 31: 741-743.

Bauer CA, Whitaker JOJ (1981) Ectoparasites of muskrats from indiana with special emphasis on spatial distribution of coexisting mites of the genus Listrophorus. American Midland Naturalist 105: 112-123.

Bebić N (1955) [Pests in Kosmet during 1953 and 1954] (in Serbian). Plant protection, 30: 85-91. Berggren A (2005) Effect of the blood-sucking mite Ornithonyssus bursa on chick growth and fledging age in the North Island robin. New Zealand Journal of Ecology 29: 2430-2500.

Bernini F, Castagnoli M, Nannelli R (1995) Arachnida Acari. In Minelli A, Ruffo S, La Posta S (Eds) Checklist delle specie della fauna italiana, 24. Bologna: Calderini, 24-66.

Bigliocchi F, Maroli M (1995) Distribution and abundance of house-dust mites (Acarina: Pyroglyphidae) in Rome, Italy. Aerobiologia 11: 35-40.

Boczek J (1964) Studies on mites (Acarina) living on plants in Poland. IV Bulletin de l'Académie des Sciences Polonaises 12: 365-369.

Boczek J, Kropczynska D (1964) Studies on mites (Acarina) living on plants in Poland I. Fragmenta Faunistica Warszawa 11: 161-188.

Bolland HR, Gutierrez J, Flechtmann CHW (1998) World catalogue of the spider mite family (Acari: Tetranychidae). Leiden: Brill Academic Publishers. 392 pp. 
Bowman CE, Bartlett PW (1978). Panonychus citri (McGregor) (Acari: Tetranychidae) infesting imported Citrus mitis in England. Plant Pathology 27: 201.

Bowman DD, Lynn RC, Eberhard ML (2003) Georgi's Parasitology for Veterinarians. 8.ed. St. Louis: Saunders. 422p.

Bozai J (1970) Determination key for spider mites. Növényvédelen (Plant protection) 10: 455-460

Bozai J (1974) Contributions to the knowledge of the Tetranychoid fauna of Hungary (Acari). Folia Entomologica Hungarica 27: 5-7.

Brotóns NJ, Estrada-Peña A (2004) Survival of tick colonies on captive imported reptiles in Spain. In Abstracts of the 7th International Symposium on pathology and medicine of reptiles and amphibians. Berlin, Germany.

CAB-International (1986) Distribution maps of plant pests. Wallingford, UK.

Carmona MM (1992) Acaros fitofagos e predadores da Ilha da Madeira - II. Boletín de Sanidad Vegetal, Plagas 18: 469-482.

Castagnoli M, Oldfield GN (1996) Other Fruit Trees and Nut Trees. In: Lindquist EE, Sabelis MW, Bruin J (Eds) Eriophyoid Mites, Their Biology, Natural Enemies and Control, 6. Amsterdam: Elsevier, 543-559.

Castagnoli M, Nannelli R, Simoni S (2006) Un nuovo temibile fitofago per la fauna italiana: Tetranychus evansi (Baker e Pritchard) (Acari Tetranychidae). Informatore Fitopatologico 2006: 50-52.

Černý V (1985) First case of introduction of the tick Rhipicephalus sanguineus to Czechoslovakia. Folia Parasitologica 32: 162.

Channabasavanna GP (1996) Sugarcane, coffee and tea. In: Lindquist EE, Sabelis MW, Bruin J (Eds) Eriophyoid Mites, Their Biology, Natural Enemies and Control, 6. Amsterdam: Elsevier, 631-640.

Childers CC, French JV, Rodrigues JCV (2003). Brevipalpus californicus, B. obovatus, B. phoenicis, and B. lewisi (Acari: Tenuipalpidae): a review of their biology, feeding injury and economic importance. Experimental and Applied Acarology 30: 5-28.

Childers CC, Rodrigues JCV, Welbourn WC (2003) Host plants of Brevipalpus californicus, B. obovatus, and B. phoenicis (Acari: Tenuipalpidae) and their potential involvement in the spread of one or more viruses. Experimental and Applied Acarology 30: 29-105.

Ciampolini M, Rota P (1972) Presenza in Italia di Panonychus citri (McGregor) (Acarina, Tetranychidae). Bollettino di Zoologia Agraria e di Bachicoltura 11: 195-205.

Ciglar I, Barić B (1998) Pernicious insects and mites fauna in Croatian orhards. Entomologia Croatica 4: 63-69.

Cole JS, Sabol-Jones M, Karolewski B, Byford T (2005) Ornithonyssus bacoti infestation and elimination from a mouse colony. Contemporary Topics in Laboratory Animal Science 44: $27-30$.

Colin ME (1982) “La Varroatose." Le Point Vétérinaire 14: 21-28.

Croft BA, Pratt PD, Koskela G, Kaufman D (1998) Predation, reproduction, and impact of phytoseiid mites (Acari: Phytoseiidae) on cyclamen mite (Acari: Tarsonemidae) on strawberry. Journal of Economic Entomology 91: 1307-1314. 
Dautel H, Kahl O (1999) Ticks (Acari: Ixodoidea) and their medical importance in the urban environment. In: Robinson WH, Rettich F, Rambo GW (Eds) Proceedings of the Third International Conference on Urban Pests, 19-22 July 1999, Prague, Czech Republic, 73-82.

De Rycke PH, Joubert JJ, Hossein Hosseinian S, Jacobs FJ (2002) “The possible role of Varroa destructor in the spreading of American foulbrood among apiaries." Experimental and Applied Acarology 27: 313-318.

Delrio G, Ortu S, Prota R (1979) Aspects of integrated control in the citrus cultures of Sardinia. Studi Sassaresi 27: 205-232.

Denmark HA (1968) (revised 2006) Phalaenopsis mite, Tenuipalpis pacificus Baker (Acarina: Tenuipalpidae). Entomology Circular 74: 1p.

Denmark HA (1978) A mite, Brevipalpus russulus (Boisduval 1867) in Florida (Acarina: Tenuipalpidae). Entomology Circular 188: 1-2.

Denmark HA, Cromroy HL (2008) Tropical Fowl Mite, Ornithonyssus bursa (Berlese) (Arachnida: Acari: Macronyssidae). Bulletin EENY-297. Gainesville, Florida: University of Florida. 3 pp.

Deutsche Dahlien, Fuchsien, Gladiolen und Kübelpflanzen. Fuchsiengallmilbe. http://www. ddfgg.de/Allgemein/aktuell/Archiv/index_Fuchsiengallmilbe_2.html.

Dobosz R, Skorupska A, Blaszak C (1995) The appearance of spider mites (Tetranychidae) in parks of Poznan. In: Boczek J, Ignatowicz S, Materialy z Sympozjum na temat: "Osiagniecia Akarologii w Polsce”, Komitet Ochrony Roslin Polska Akademia Nauk, Siedlce, 39-42.

Drenski P (1955) Săstav i razprostranenie na kărležite (Ixodoidea) v Bălgarija (s ogled na medicinskoto i veterinarnoto im značenie [Artbestand und Verbreitung der Zecken (Ixodoidea) in Bulgarien (im Hinblick auf ihre medizinische und tierärtztliche Bedeutung)].(in Bulgarian, Russian and German summary). Bulletin of the Institute of Zoology (Sofija) 4-5: 109-168.

Easterbrook MA 1996. Damage and Control of Eriophyoid Mites in Apple and Pear. In: Lindquist EE, Sabelis MW, Bruin J (Eds) Eriophyoid Mites, Their Biology, Natural Enemies and Control, 6. Amsterdam: Elsevier, 527-541.

Easterbrook JD, Kaplan JB, Glass GE, Watson J, Klein SL (2008) A survey of rodent-borne pathogens carried by wild-caught Norway rats: a potential threat to laboratory rodent colonies. Laboratory Animals 42: 92-98.

Emmanouel NG, Papadoulis GT (1987) Panonychus citri (MacGregor) (Tetranychidae) and Eriophyes medicaginis K. (Eriophyidae): two important phytophagous mites recorded for the first time in Greece. Entomologia Hellenica 5: 3-6.

EPPO (2002) List of biological control agents widely used in the EPPO region. EPPO Bulletin 32: 447-461.

Eriksson NE (1990) Allergy screening with Phadiatop and CAP Phadiatop in combination with a questionnaire in adults with asthma and rhinitis. Allergy 45: 285-292.

Estación Fitopatolóxica do Areeiro. Cosetacus camelliae (Keifer). Camellia flower bud drop. http://www.efa-dip.org/en/Publicaciones/FTecnicas/Ficha9_1.htm.

Estrada-Peña A, unpublished observations.

Evans WD, Krantz G, Lindquist E (1996) Acari. The Mites. Version 13 December 1996. http:// tolweb.org/Acari/2554/1996].12.13 in The Tree of Life Web Project, http://tolweb.org/. 
Fan Y, Petit FL (1998) Dispersal of the broad mite, Polyphagotarsonemus latus (Acari: Tarsonemidae) on Bemisia argentifolii (Homoptera: Aleyrodidae). Experimental and Applied Acarology 22: 411-415.

Fauna Europaea. http://www.faunaeur.org.

Fauna Italia. Eriophyidae. http://www.faunaitalia.it/checklist/invertebrates/families/Eriophyidae.html.

Feider Z (1965) Arachnida, Volumul V, Fascicula 2. Acaromorpha, Suprafamilia Ixodoidea (Capuse). In: Fauna Republicii Populare Romane. Bucarest: Editura Academiei Republicii Populare Romane, Romania, 89-104.

Ferragut F, Escudero LA (1999) Tetranychus evansi Baker \& Pritchard (Acari, Tetranychidae), una nueva araña roja en los cultivos horticolas españoles. Boletín de Sanidad Vegetal, Plagas 25: $157-164$.

Ferragut F, Escudero LA, Olmeda T (1997) Tetranychus evansi Baker \& Pritchard (Acari: Tetranychidae), una nueva araña roja en los cultivos hortícolas españoles. Resúmenes de las VI Jornadas Cientificas de la Sociedad Española de Entomología Aplicada. Leida, Spain: Edicións Universitat de Lleida: 66.

Ferragut F, Santonja MC (1989) Taxonomia y distribucion de los acaros del genero Tetranychus Dufour 1832 (Acari: Tetranychidae), en Espana Boletin de Sanidad Vegetal, Plagas 15: 271-281.

Ferreira MA, Carmona MM (1995) Acarofauna do tomateiro em Portugal. Avances en Entomologia Ibérica, Museo Nacional Ciencias Naturales y Universidad de Madrid: 385-392.

Garben AF, Bosman BT, Bronswijk JEMH v (1980) [The brown dog tick Rhipicephalus sanguineus Latreille 1806 in the Netherlands, an analysis of imported cases, including their veterinary and medical significance] (in Dutch). Tijdschrift voor Diergeneeskunde 105: 192-203.

Garcia E, Marquez AL, Orta S, Alvarado P (2003) Caracterizacion de la presencia de Eutetranychus banksi (McGregor) y Eutetranychus orientalis (Klein) en el Sur de Espana. Phytoma - España 153: 90-96.

Garcia Mari F, de Rivero JM (1981) El acaro rojo Panonychus citri (McGregor), nueva plaga de los citricos en Espana. Boletin del Servicio de Defensa contra Plagas e Inspeccion Fitopatologica 7: 65-77.

Garcia Mari F, Gonzalez-Zamora JE (1999) Biological control of Tetranychus urticae (Acari: Tetranychidae) with naturally occurring predators in strawberry plantings in Valencia, Spain. Experimental and Applied Acarology 23: 487-495.

Gerson U (1992) Biology and control of the broad mite, Polyphagotarsonemus latus (Banks) (Acari: Tarsonemidae). Experimental and Applied Acarology 13: 163-178.

Gjelstrup P, Møller AP (1985) A tropical mite, Ornithonyssus bursa (Berlese, 1888) (Macronyssidae, Gamasida) in Danish Swallow (Hirundo rustica) nests, with a review of mites and ticks from Danish birds. Entomologiste Meddelelser 53: 119-125.

Glavendekić M, Mihajlović LJ, Petanović R (2005) Introduction and spread of invasive mites and insects in Serbia and Montenegro In Plant protection and plant health in Europe. In: Abstracts of the Conference Plant Protection and Plant Health in Europe, 'Introduction and spread of invasive species', Berlin, Germany: Humboldt University, June 2005. 
González Núñez M, Budia F, Viñuela E, Esteban Durán JR, Adan A, Medina P, Schneider M, Del Estal P (2002) Primera cita en Espańa del eriófido de la alcachofa Aceria neocynarae (Keifer). Boletín de Sanidad Vegetal, Plagas 28: 415-418.

Griffiths DA, Bowman CE (1981) "World distribution of the mite Varroa jacobsoni, a parasite of honeybee." Bee World 62: 154-163.

Guttierez J, Kreiter S, Brain F, Cotton D (1986) Les acariens, ravageurs mal connus du cypress. Phytoma-La défense des végétaux 376: 47-48.

Hadžistević D (1955) [Occurence of agricultural pests during twenty years (1934-1953) in Yugoslavia]. Plant protection (in Serbian) 27: 89-120.

Harbo JR, Harris JW (2005) Suppressed mite reproduction explained by the behavior of adult bees. Journal of Apicultural Research 44: 21-23.

Hance T, Neuberg P, Noel-Lastelle C (1998) The use of fecundity, lobe biometry and the RAPD-PCR technique in order to compare strains of Tetranychus sp. Experimental \& Applied Acarology, 22: 649-666.

Hatzinikolis EN (1968) Liste d'acariens de la sous-famille Tetranychinae trouvés sur les plantes cultivées en Grèce. Annales de l'Institut Phytopathologique Benaki 8: 193-194.

Hatzinikolis EN (1970) Neuf espèces d'acariens signalées pour la première fois en Grèce. Annales de l'Institut Phytopathologique Benaki 9: 238-241.

Hatzinikolis EN (1986) The genus Tetranychus Dufour, 1832, in Greece (Acari : Tetranychidae). Biologia Gallo-hellenica 12: 383-388.

Helle W, Sabelis MW (eds.) 1985. Spider mites: their biology, natural enemies and control. Vol. 1A. Amsterdam, The Netherlands: Elsevier. 405 pp.

Hetenyi E (1954) A gyapoton é lö takacsatkak (Tetranychus urticae Koch) és az ellen ük valo védekezés. Növényvédelen (Plant protection) 1: 11-19.

Heungens A (1986) Soft-skinned mites in azalea culture and comparable control results on other host plants. Verbondsnieuws voor de Belgische Sierteelt 30: 257-269.

Hoogstraal, H. (1956) African Ixodoidea. Ticks of the Sudan. Cairo, Egypt: U.S. Naval Medical Research Unit., 1099 pp.

Hoogstraal H (1979) The epidemiology of tick-borne Crimean-Congo hemorrhagic fever in Asia, Europe and Africa. Journal of Medical Entomology 15: 307-417.

Hughes AM (1976) The mites of stored foods and houses. Technical bulletin of the ministry of agriculture. London: Technical Bulletin of the Ministry of Agriculture, Fisheries \& Food, No. 9. 400 pp.

James DK (2005) Biting mites in homes of Alameda county. Alameda County Vector Control Services District. http://www.acvcsd.org/ biting_mites.pdf.

Jeppson LR, Keifer HH, Baker EW (1975) Mites injurious to economic plants. Berkeley, California: University of California Press. 614 pp.

Keifer HH (1975) Injurious eriophyoid mites. In Jeppson LR, Keifer HH, Baker EW (eds.) Mites injurious to economic plants. Berkeley, California: University of California Press, 397-533.

Krantz GW, Walter, D.E. (eds.) 2009. A manual of Acarology, $3^{\text {rd }}$ Edition. Lubbock, Texas: Texas Tech University Press, 807 pp. 
Kropczynska D (1984) The role of predaceous mites (Phytoseidae) as natural enemies of Eotetranychus tiliarium (Hermann) in town conditions. Publications of Warsaw Agricultural University, SGGW-AR (Treatises and Monographs): 1-68.

Labanowski GS (1999) Occurrence and chemical control of introduced ornamental glasshouse pests in Poland. OEPP/EPPO Bulletin, 29, 73-76.

Le Conte Y, de Vaublanc G, Crauser D, Jeanne F, Rousselle JC, Bécard JM (2007) Honey bee colonies that have survived Varroa destructor. Apidologie 38: 566-572.

Manson DCM (1967) Mites of the families Tenuipalpidae and Tetranychidae intercepted entering New Zealand from overseas. New Zealand Journal of Science 10: 664-674.

Margolies DC (1993) Adaptation to spatial variation in habitat: spatial effects in agroecosystems. In Ke Chung K, McPheron BA (eds.) Evolution of insects pests: patterns of variation. New York: John Wiley \& Sons Inc., 129-144.

Margolies DC (1995) Evidence of selection on spider mite dispersal rates in relation to habitat persistence in agroecosystems. Entomologia Experimentalis et Applicata 76: 105-108.

Mc Coy CW (1996) Damage and control of Eriophyoid mites in crops. Stylar feeding injury and control of Eriophyoid in citrus. Evolutionary ecology: life history patterns, food plant choice and dispersal. In: Lindquist EE, Sabelis MW, Bruin J (Eds) Eriophyoid Mites, Their Biology, Natural Enemies and Control, 6. Amsterdam: Elsevier, 513-526.

McMurtry JA, Croft BA (1997) Life-styles of phytoseiid mites and their roles in biological control. Annual Review of Entomology 42: 291-321.

Migeon A (2003) Eurytetranychus admes: un nouvel acarien tétranyque sur les cyprès en France. Phytoma - La Défense des Végétaux, 561: 30-31.

Migeon A (2005) Un nouvel acarien ravageur en France: Tetranychus evansi Baker et Pritchard. Phytoma - La Défense des Végétaux, 579: 38-43.

Migeon A (2007) Acarien rouge de la tomate: nouvelles observations et perspectives. PHM Revue Horticole, 488: 20-24.

Migeon A, Cros-Arteil S, Navajas M (2004) The use of taxonomical and ecological databases combined with the genetic approach for tracking spidermite invasions. In: Weigman $G$, Alberti G, Wolhtmann A, Ragusa S Acarine biodiversity in the natural and human sphere. Phytophaga Berlin, 14: 757-765.

Mijušković M (1953) [Quelques maladies et insectes nuisibles aux agrumes au Montenegro] (in Serbian). Zaštita Bilja, 19: 47-60.

Mijušković M (1973) [The study of mites on the Citrus trees on the Yugoslav littoral - final technical report] (in Serbian). Titograd (Podgorica), Montenegro: Agriculture Research Institute, 239.

Mijušković M, Tomašević B (1975) [The mites on the citrus trees on the Yugoslav littoral] (in Serbian). Titograd (Podgorica), Montenegro: Society for Sciences and Art of Montenegro. 204 pp.

Morel P-C, Battelli C, Sobrero L (1977) Hyalomma detritum scupense Schulze in Italia. Atti Societá italiana di Scienze veterinari 31: 739-740.

Morse RA, Goncalves LS (1979) Varroa disease, a threat to world beekeeping. Gleanings in Bee Culture 107: 179-181. 
Musken H, Franz JT, Wahl R, Paap A, Cromwell O, Masuch G, Bergmann KC (2000) Sensitization to different mite species in German farmers: Clinical aspects. Journal of Investigational Allergology and Clinical Immunology 10: 346-351.

Natarajan K (1988) Transport of yellow mite Polyphagotarsonemus latus by cotton whitefly. Current Science 57: 1142-1143.

Neumann LG (1911) Ixodidae. Tierreich 26. Berlin: R. Friedlander und Sohn. 169 pp.

Oldfield GN (1996) Diversity and host plant specificity. I In: Lindquist EE, Sabelis MW, Bruin J (Eds) Eriophyoid Mites, Their Biology, Natural Enemies and Control, 6. Amsterdam: Elsevier, 195-216.

Ostoja-Starzewski JC (2000) Schizotetranychus celarius (Banks) (Acari: Prostigmata) a mite pest of bamboo; first records for Britain and two new host records. British Journal of Entomology \& Natural History 13: 95-97.

Ostojá-Strazewski JC, Eyre D, Cannon RJ, Bartlett P (2007) Update on Fuchsia gall mite Aculops fuchsiae Keifer. Sand Hutton, York, UK: CSL, Plant pest notice. No.5I.

Ostojá-starzewski JC, Halstead AJ (2006) Trisetacus chamaecypari Smith (Acari: Phytoptdiae) damaging Leyland Cypress in Britain: a new host and country record for this mite. British Journal of Entomology and Natural History 19: 201-205.

Pande YD, Carnero A, Hernandez M (1989) Notes on biological observations on some unrecorded species of phytophagous and predatory mites in Canary. Islands Investigación agraria, Producción y protección vegetales 4: 275-281.

Papaioannou-Souliotis P, Tsagarakou A, Dermatas P (1993) Integrated pest control in citrusgroves, evaluation on new acaricides used in the treatment of citrus red mite (Panonychus citri Koch.). Bulletin Oilb/Srop 16: 125-131.

Parker R, Gerson U (1994) Dispersal of the broad mite, Polyphagotarsonemus latus (Banks) (Heterostigmata: Tarsonemidae), by the greenhouse whitefly, Trialeurodes vaporariorum (Westwood) (Homoptera: Aleyrodidae). Experimental and Applied Acarology 18: 581-585.

Pérez Otero R, Mansilla Vázquez P, Salinero Corral MC, Sainz Oses J (2003) Occurrence of Mites in CamelliaTrees Grown in Parks and gardens in Northwest Spain. American Camellia Yearbook 45-50.

Petanović R (1980) Some morphological characteristics of importance in the differentiation of Panonychus ulmi Koch. and Panonychus citri McGregor (Tetranychidae, Acarina). Interim report Arhiv Za Poljoprivredne Nauke 41: 517-522.

Petanović R (1988) Eriofidne grinje u Jugoslaviji (Monografija). Beograd: Naučna knjiga. 159 pp.

Petanović R (1993) Pregled vrsta eriofida (Acari: Eriophyoidea) šumskih i ukrasnih biljaka na prostorima južnoslovenskih zemalja. XXI skup entomologa Jugoslavije. Beograd, 1718.11.1993. Zbornik rezimea, str. 22.

Petanović R (1997) Allochthonous mite species (Acari) in the fauna of Yugoslavia. Zastita Bilja 48: $211-224$.

Petanović R (1998) New data to the knowledge on the eriophyoid fauna (Acari: Eriophyoidea) in Yugoslavia. Acta Entomologica Serbica 3: 149-157.

Petanović R (1999) Three New Species of Eriophyid Mites (Acari: Eriophyoidea) from Serbia with the Notes on New Taxa for the Fauna of Yugoslavia. Acta Entomologica Serbica 4: 127-137. 
Petanović R (2004) [Atlas - Mite pests of decorative plants] ( in Serbian). Beograd: Beografik. 99 pp. Petanović R (in prep.) Database of Eriophyoid mite fauna of Serbia. Still not available on the internet. Petanović R, Boček J, Jovanović S, Stojnić B (1996) [Eriophyoidea (Acari: Prostigmata) Fauna Durmitora, 5] (in Serbian). CANU, Posebna izdanja, knjiga 32, Odjeljenje prirodnih nauka, knjiga 18, Podgorica.

Petanović R, Dobrivojević K (1987) Kompleks galikolnih eriofida lista šljive. Zaštita bilja 38: $145-156$.

Petanović R, Dobrivojević K, Boczek J, Lazić S (1983) Eriofidne grinje (Eriophyoidea: Acarina) na korovskim biljkama u okolini Beograda. Arhiv za poljoprivredne nauke 44, 156 (1983/4): 455-460.

Petanović R, Mihajlović LJ, Mihajlović N, Magud B (1997) Reckella celtis Bog. and Aceria bezzi (Corti) (Acari: Eriophyoidea). Two new Species in the Balkan Fauna. Acta Entomologica Serbica 2: 95-106.

Petanović, R. i S. Stanković (1999) Catalogue of the Eriophyoidea (Acari: Prostigmata) of Serbia and Montenegro. Acta Entomologica Serbica, special issue: 1-143.

Piotrowski F (1990) Zarys entomologii parazytologicznej. Warszawa: PWN 5.301 pp.

Raemaekers RHE (2001) Agriculture en Afrique Tropicale. Bruxelles: Direction Générale de la Coopération Internationale. $1634 \mathrm{pp}$.

Ragusa S (2002) As time goes by: a profile of Italian acarology. In Bernini F, Nannelli R, Nazzaci G, De Lillo E (eds) Acari Phylogeny and Evolution. Adaptations in mites and ticks. Dordrecht, The Netherlands: Kluwer Academic Publishers, 1-20.

Rambier A (1958) Les acariens nuisibles en cultures fruitières. Comptes-Rendus des Journées Fruitières et Maraichères, Avignon: 59-64.

Rambier AM (1982) Un acarien, sur vigne en Champagne, nouveau en France: Tetranychus mcdanieli McGregor 1931 du groupe pacificus. Le Progrès Agricole et Viticole 99: 261-263

Razowski J (1997) (Ed) Wykaz zwierząt Polski IV. [Checklist of animals of Poland] (in Polish). Kraków, Poland: Wydawnictwa Instytutu Systematyki i Ewolucji Zwierząt. 303 pp.

Rigamonti IE, Lozzia GC (1999) Injurious and beneficial mites on urban trees in Northern Italy. Acta Horticulturae 496: 177-182.

Ripka G (2007) Checklist of the eriophyoid mite fauna of Hungary (Acari:.Prostigmata: Eriophyoidea). Acta Phytopathologica et Entomologica Hungarica 42:59-142.

Ripka G, De Lillo E (1997) New data to the knowledgeon the eriophyoid fauna in Hungary (Acari: Eriophyoidea). Folia Entomologica Hungarica 58, 147-157.

Robbins RG, Karesh CPP, Leontyeva OA, Pereshkolnik SL, Rosenberg S (1998) First records of Hyalomma aegyptium (Acari: Ixodida; Ixodidae) from the Russian spur-thighed tortoise, Testuda graeca nikolskii, with an analysis of tick population dynamics. Journal of Parasitology 84: 1303-1305.

Rosicky B, Cerny V, Luli M (1960) Contribution à l'étude sur la présence, la distribution et al bionomie des tiques (Ixodoidea) en Albanie. Ceskoslov Parasit 7: 159-188.

Rota P, Biraghi C (1987) Oligonychus ilicis (Mc Gregor): a tetranychid mite new to Europe, phytophagous on azaleas, camellias and rhododendrons. L'Informatore Agrario 43: 105-107 Ruttner F (1983) Varroatosis in honeybees: Extent of infestation and effects. Meeting of the EC Experts' Group, The Netherlands, Wageningen. 
Ruttner F, Marx G (1984) "Beobachtungen über eine mögliche Anpassung von Varroa jacobsoni an Apis mellifera L. in Uruguay." Apidologie 15: 43-62.

Sabelis MW, Bruin J (1996) Evolutionary ecology: life history patterns, food plant choice and dispersal. In: Lindquist EE, Sabelis MW, Bruin J (Eds) Eriophyoid Mites, Their Biology, Natural Enemies and Control, 6. Amsterdam: Elsevier, 329-365.

Schulze P (1927) Beitrage zur Kentniss der Zecken Europas. Sitzungsberichte der Gesellschaft Naturforschender Freunde zu Berlin 1: 109-126.

Schulze P, Schlottke E (1929) Bestimmungstabellen fuer das Zeckengenus Hyalomma Koch s. str. Sitzungsberichte und Abhandlungen der Naturforschenden Gesellschaft zu Rostock 3: 32-46.

Šefrová H, Laštůvka Z (2005) Acta Universitatis Agriculturae et Silviculturae Mendelianae Brunensis 53: 151-170.

Sengonca C, Zegula T, Blaeser P (2004) The suitability of twelve different predatory mite species for the biological control of Frankliniella occidentalis (Pergande) (Thysanoptera: Thripidae). Zeitschrift für Pflanzenkrankheiten und Pfanzenschutz 111: 388-399.

Shetchenko VG, Rupais AA (1964) Four Leggd Mites (Acarina:Eriophyidae)- pests of parks in Latvia. Fauna Latviskoi SSR,IV, Riga: 203-239.

Sibomana G, Geerts S, De Vries T (1986) L'établissement de Rhipicephalus sanguineus (Latreille, 1806) à l'intérieur des maisons en Belgique. Annales de la Société belge de médecine tropicale 66 : 79-81.

Siroky P, Petrzelkova KJ, Kamler M, Mihalca A, Modry D (2007) Hyalomma aegyptium as dominant tick in tortoises of the genus Testudo in Balkan countries, with notes on its host preferences. Experimental and applied Acarology 40: 279-290.

Smith TG (1996) The genus Hepatozoon (Apicomplexa: Adeleina). Journal of Parasitology 82: $565-585$.

Smith RM, Baker RHA, Malumphy CP, Hockland S, Hammon RP, Ostojá-Starzewski JC, Collins DW (2007) Recent non-native invertebrate plant pest establishments in Great Britain: origins, pathways, and trends. Agricultural and Forest Entomology. 9, 307-326.

Soika G, Labanowski GS (1998) Nowe gayunki szpecieli (Eriophyoidea) w szkolkach roslin ozdobnych. Progress in Plant Protection 38: 416-418.

Soika G, Labanowski GS (1999) Szpeciele-sprawcy wyrosli I zneiksztalcen na roslinach ozdobnych. Progress in Plant Protection 39: 537-540.

Solignac M, Cornuet J, Vautrin D, Le Conte Y, Anderson D, Evans J, Cros-Arteil S, Navajas M (2005) The invasive Russian and Japanese types of Varroa destructor, ectoparasite mite of the Western honey bee (Apis mellifera), are two partially isolated clones. Proceedings of the Royal Society of London B, 272: 411-419.

Thind BB, Clarke P (2001) The occurrence of mites in cereal-based foods destined for human consumption and possible consequences of infestation. Experimental and Applied Acarology 25: 203-215.

Trotter A (1903) Galle della Penisola Balcanica e Asia Minore. Nuovo Giornale botanico Italiano N.S.X. 5-54: 210-233.

Vacante V (1983) Prima raccolta di Acari Tetranichidi in Sicilia. Phytophaga 1: 41-114. 
Van Houten YM, van Stratum P (1993) Biological control of western flower thrips in greenhouse sweet peppers using nondiapausing predatory mites. Experimental and Applied Ac$\operatorname{arology}$ 4: 229-234.

Van Houten YM, van Stratum P (1995) Control of western flower thrips on sweet pepper inwinterwith Amblyseius cucumeris (Oudemans) and A. degenerans Berlese. NATO ASI series A, Life Sciences 276: 245-248.

Vappula NA (1965) Pest of cultivated plants in Finland. Acta Entomologica Fennica 19: 1-239.

Vierbergen G (1989) Panonychus citri - na vele malen geïmporteed, tenslotte geïntroduceerd. Verslagen en Medelingen Plantenziektenkundige Dients Wageningen 167: 52-53.

Vierbergen G (1990) The spider mites of the Netherlands and their economic significance (Acarina: Tetranychidae). Proceedings of the Section Experimental \& Applied Entomology of the Netherlands Entomological Society 1: 158-164.

Vierbergen G (1994) Entomology. Panonychus citri: a pest in the subtropics, found in the Netherlands in the open. Wageningen: Medelingen, Plant Protection Service, Diagnostic Centre, Annual Report 173: 28-30.

Wharton GW, Hansell FC (1957) Studies on the feeding habits of three species of Laelaptid mites. Journal of Parasitology 43: 45-50.

Whitaker JOJ, Walters BL, Castor LK, Ritzi CM, Wilson N (2007) Host and distribution lists of mites (acari), parasitic and phoretic, in the hair or on the skin of North American wild mammals North of Mexico: Records since 1974. Faculty Publications from the Harold W. Manter Laboratory of Parasitology, 1-173.

Witters J, Casteels H, de Bondt G (2003) Diagnostic acarological research at the Department of Crop Protection in 2002-2003. Parasitica 59, 107-111. 


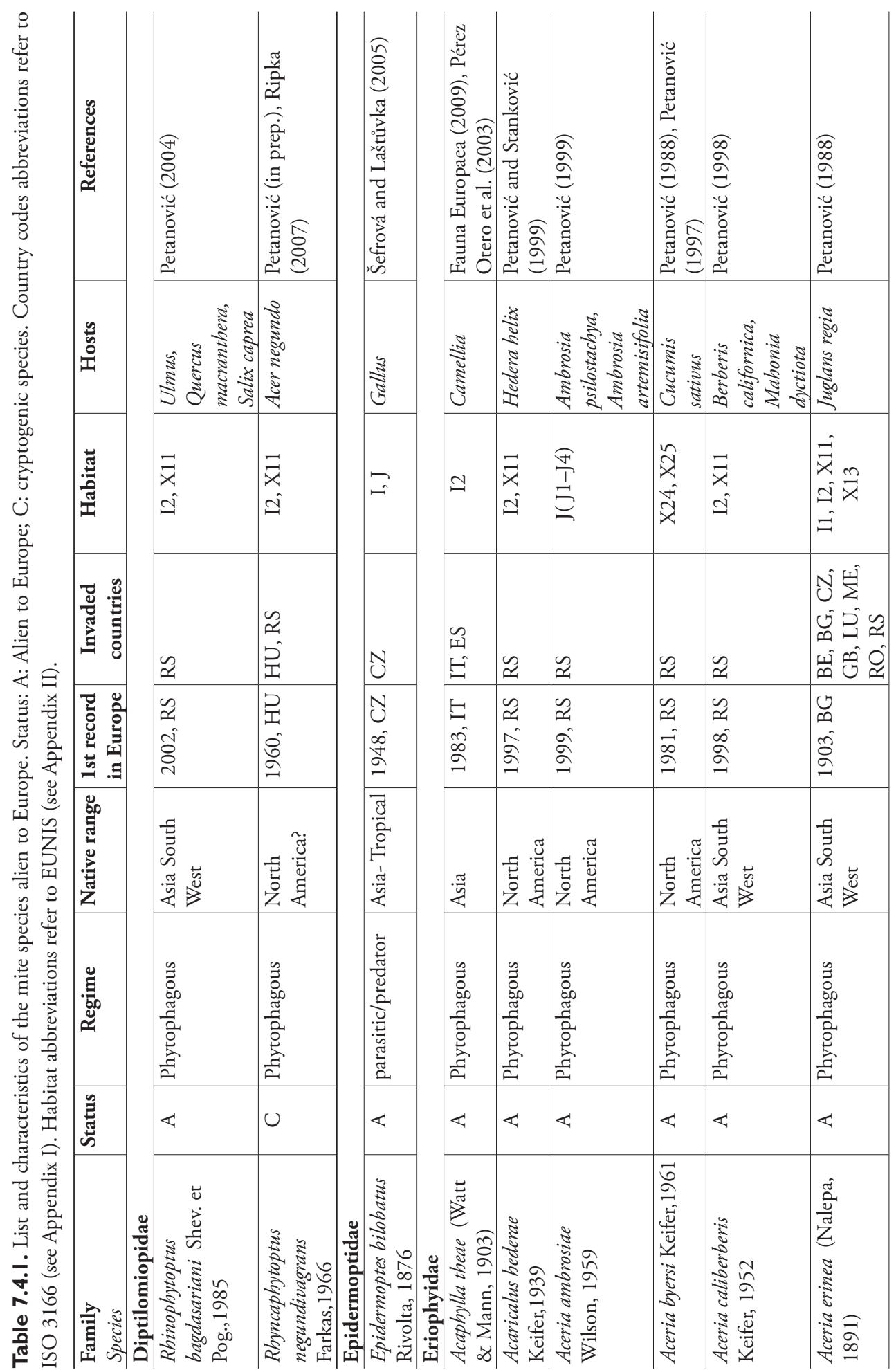




\begin{tabular}{|c|c|c|c|c|c|c|c|c|c|c|}
\hline 怤 & 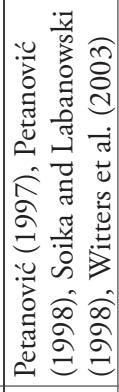 & 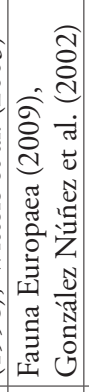 & 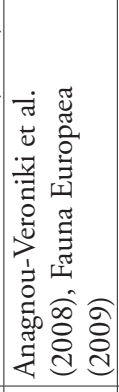 & 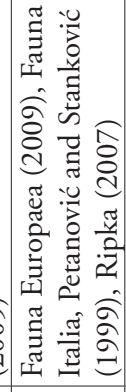 & 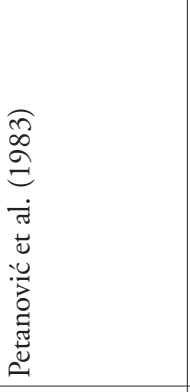 & 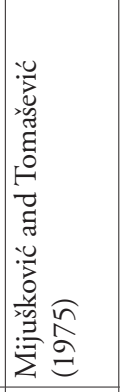 & 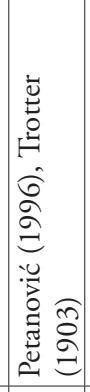 & & 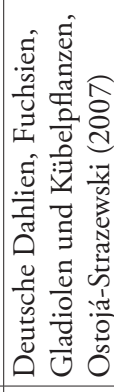 & 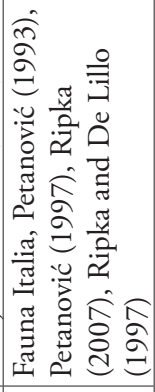 \\
\hline $\begin{array}{l}\stackrel{0}{0} \\
\stackrel{0}{I}\end{array}$ & 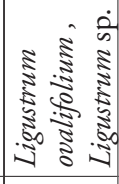 & 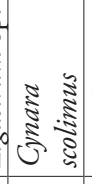 & 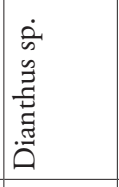 & 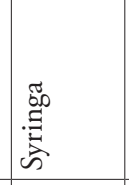 & 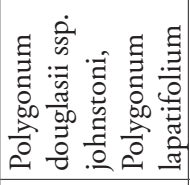 & $\frac{0}{3}$ & 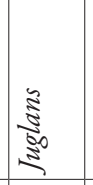 & & \begin{tabular}{|l}
3 \\
$\frac{1}{3}$ \\
$\frac{3}{3}$ \\
-3
\end{tabular} & 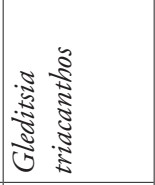 \\
\hline 苞 & $\begin{array}{l}\exists \\
\bar{x} \\
\infty \\
\underline{\mid c} \\
\tilde{a}\end{array}$ & - & $\underset{\Xi}{\stackrel{8}{二}}$ & $\begin{array}{l}\overline{\bar{x}} \\
\approx\end{array}$ & $\begin{array}{l}\stackrel{f}{1} \\
\stackrel{5}{\Xi}\end{array}$ & $\begin{array}{l}m \\
\ddot{x}\end{array}$ & $\frac{m}{x}$ & & 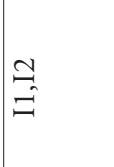 & $\overline{\bar{x}}$ \\
\hline 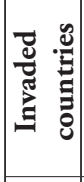 & 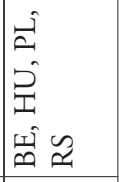 & 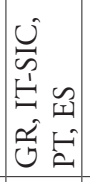 & 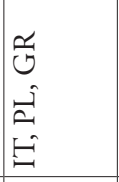 & 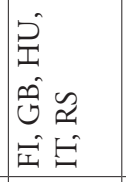 & $\approx$ & 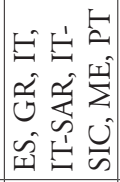 & 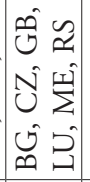 & $\begin{array}{c}0 \\
\not 1 \\
\hat{N} \\
0 \\
0 \\
0\end{array}$ & 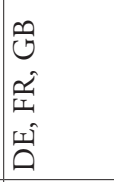 & 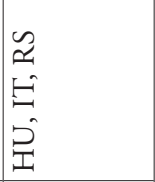 \\
\hline 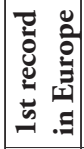 & $\begin{array}{l}\approx \\
\approx \\
\approx\end{array}$ & $\begin{array}{l}\tilde{y} \\
1 \\
\infty \\
2 \\
2\end{array}$ & 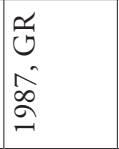 & 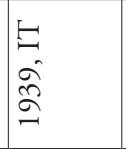 & $\begin{array}{l}\mathscr{2} \\
\hat{\infty} \\
\cong\end{array}$ & $\begin{array}{l}\qquad \\
\stackrel{\Xi}{=}\end{array}$ & $\begin{array}{l}\mathscr{2} \\
\approx \\
\approx \\
\approx\end{array}$ & 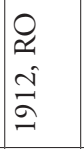 & 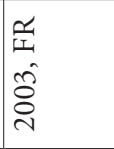 & $\begin{array}{l}\approx \\
\approx \\
\approx \\
\approx\end{array}$ \\
\hline 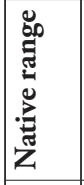 & 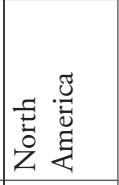 & 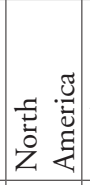 & 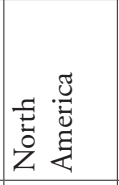 & 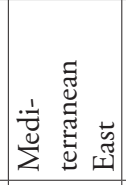 & 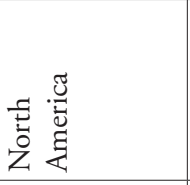 & 落 & 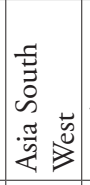 & 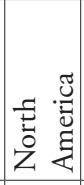 & 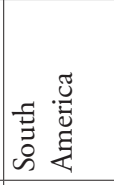 & 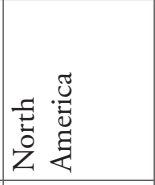 \\
\hline 薃 & 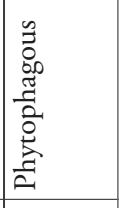 & 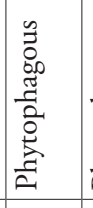 & 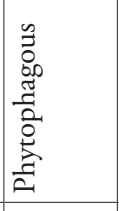 & 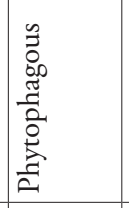 & 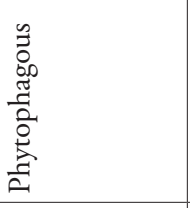 & 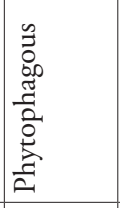 & 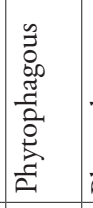 & 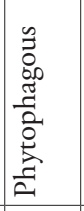 & 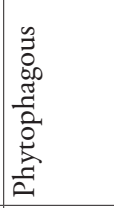 & 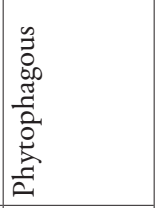 \\
\hline 苞 & $\ll$ & $\varangle$ & $\varangle$ & $\ll$ & $\ll$ & $\varangle$ & $\varangle$ & $\ll$ & $\ll$ & $\ll$ \\
\hline 赵 & 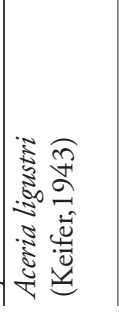 & 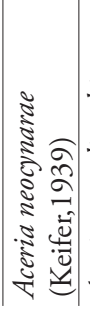 & 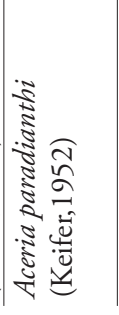 & 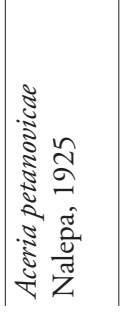 & 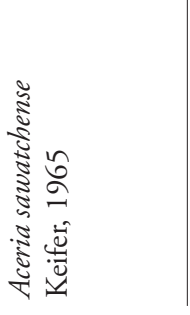 & 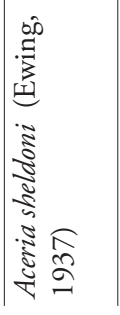 & 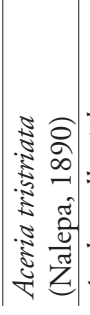 & 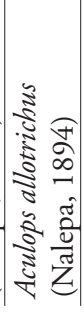 & 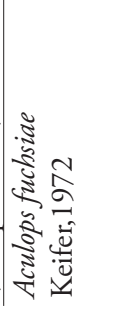 & 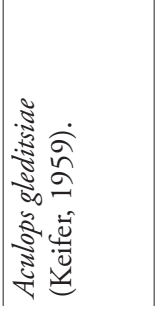 \\
\hline
\end{tabular}




\begin{tabular}{|c|c|c|c|c|c|c|c|c|c|c|}
\hline 怤 & 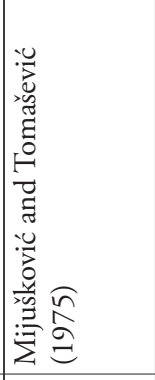 & 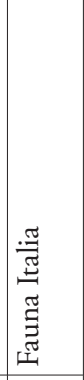 & 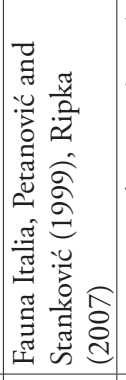 & 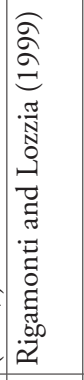 & 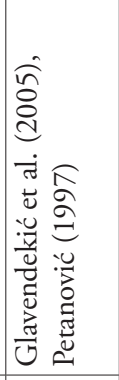 & 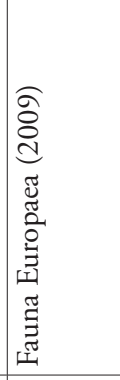 & 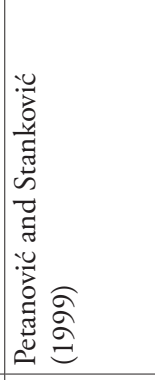 & 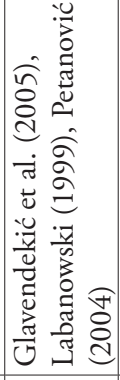 & 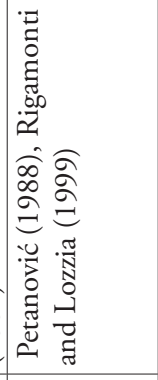 & 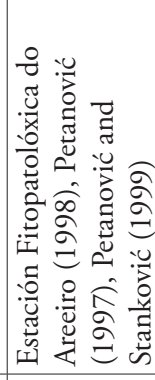 \\
\hline 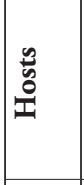 & 离 & 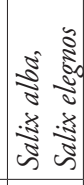 & 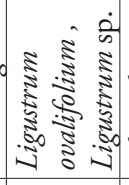 & 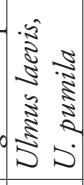 & 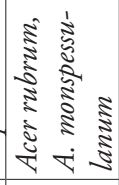 & 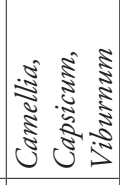 & 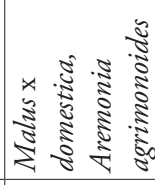 & 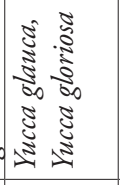 & 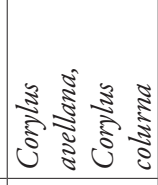 & 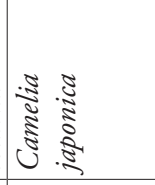 \\
\hline 苛 & $\stackrel{m}{x}$ & $\begin{array}{l}\frac{m}{x} \\
\overline{\bar{x}}\end{array}$ & $\begin{array}{l}m \\
\vec{x} \\
\overrightarrow{\bar{x}}\end{array}$ & $\begin{array}{l}\stackrel{\varphi}{I} \\
\hat{\imath}\end{array}$ & $\frac{m}{\bar{x}}$ & $\simeq$ & $\stackrel{m}{x}$ & $\begin{array}{l}E \\
\dot{8} \\
E\end{array}$ & $\begin{array}{l}m \\
\vec{x} \\
\hat{p} \\
\hat{I} \\
\hat{a}\end{array}$ & $\begin{array}{l}8 \\
\varrho \\
\approx \\
\approx\end{array}$ \\
\hline 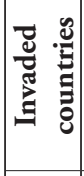 & 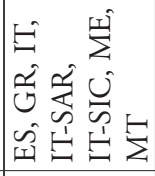 & 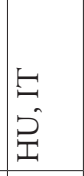 & 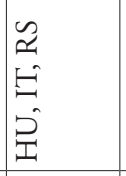 & $છ$ & $\mathscr{\approx}$ & 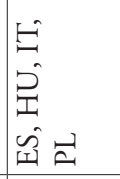 & $\mathscr{\approx}$ & $\begin{array}{l}\vec{a} \\
\tilde{2} \\
\tilde{2}\end{array}$ & 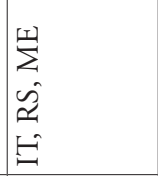 & $\begin{array}{l}n \\
\sum \\
\infty \\
1 \\
1\end{array}$ \\
\hline 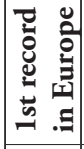 & 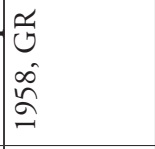 & 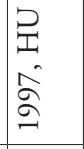 & $\begin{array}{l}\models \\
\ddot{2} \\
\check{\beth}\end{array}$ & 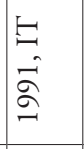 & $\begin{array}{l}\mathscr{\simeq} \\
2 \\
2 \\
2\end{array}$ & $\begin{array}{l}\models \\
\cdots \\
\infty \\
\cong\end{array}$ & $\begin{array}{l}\mathscr{2} \\
\hat{a} \\
\approx\end{array}$ & 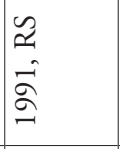 & $\begin{array}{l}\mathscr{\approx} \\
\hat{\infty} \\
\infty \\
\approx\end{array}$ & 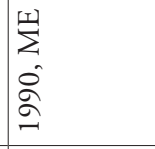 \\
\hline 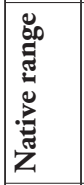 & $\frac{.5}{4}$ & 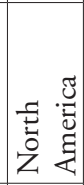 & 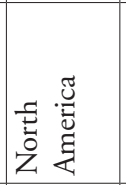 & 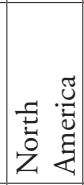 & 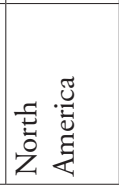 & $\frac{.5}{4}$ & 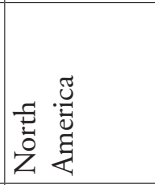 & 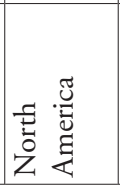 & 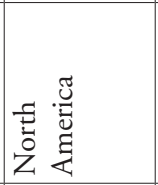 & 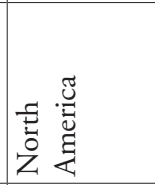 \\
\hline 薃 & $\begin{array}{l}0 \\
0 \\
0 \\
0 \\
\frac{0}{0} \\
0 \\
0 \\
\vdots \\
\frac{1}{1} \\
1\end{array}$ & 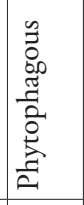 & 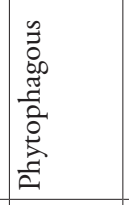 & 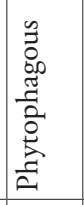 & 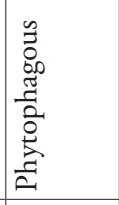 & 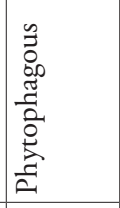 & 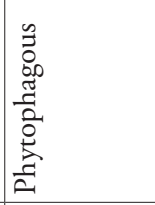 & 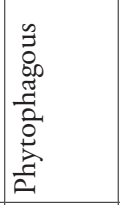 & 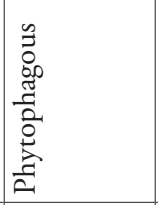 & 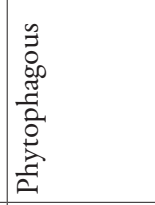 \\
\hline 氙 & $\varangle$ & $\ll$ & $\ll$ & $\varangle$ & $\ll$ & $\ll$ & $\varangle$ & $\varangle$ & $\varangle$ & $\varangle$ \\
\hline 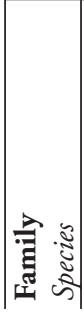 & 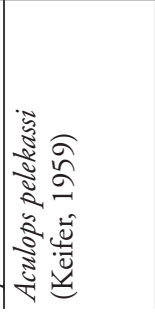 & 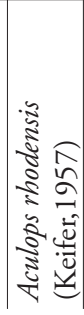 & 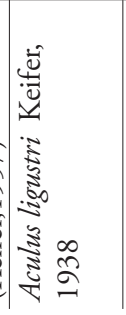 & 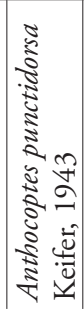 & 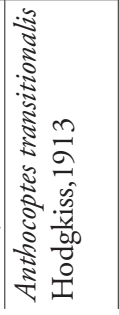 & 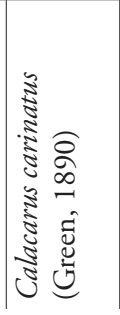 & 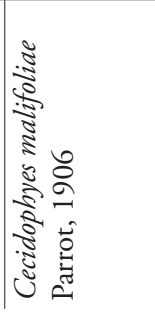 & 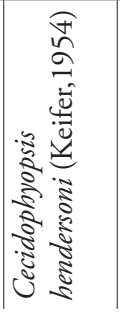 & 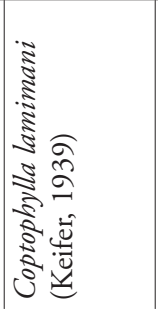 & 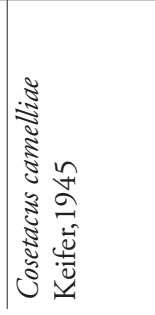 \\
\hline
\end{tabular}




\begin{tabular}{|c|c|c|c|c|c|c|c|}
\hline & 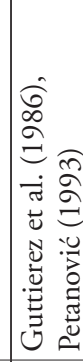 & 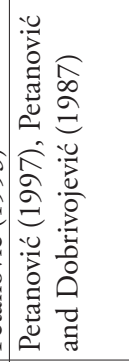 & 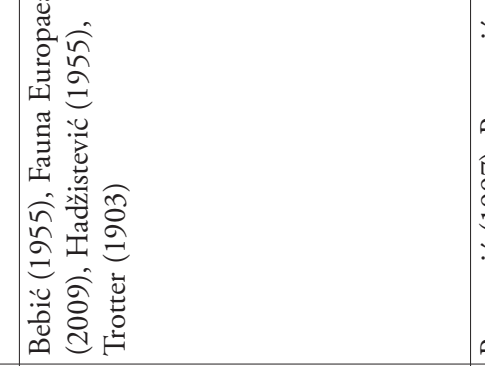 & 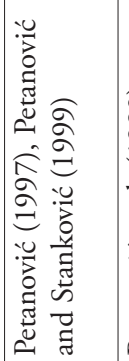 & 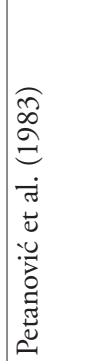 & & 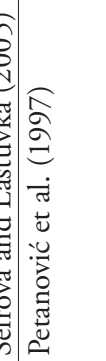 \\
\hline 或 & & 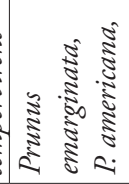 & 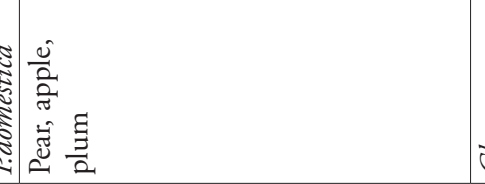 & 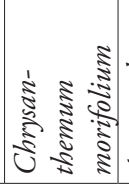 & & 齐 & 急 \\
\hline 遏 & $\simeq$ & $\begin{array}{l}\vec{y} \\
\hat{n} \\
x \\
-1 \\
-1\end{array}$ & - & 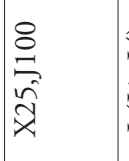 & 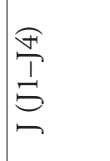 & ט & $\begin{array}{l}\vec{m} \\
\vec{x} \\
\vec{j}\end{array}$ \\
\hline 过 & 甚 & $\approx$ & 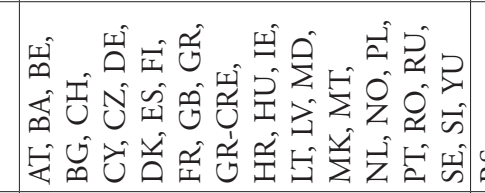 & & $\approx$ & 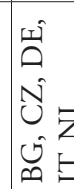 & $\frac{2}{2}$ \\
\hline 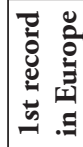 & 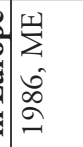 & $\begin{array}{l}\approx \\
\approx \\
\infty \\
2 \\
2\end{array}$ & 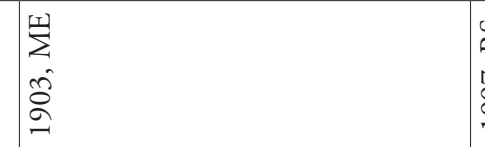 & 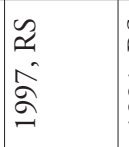 & 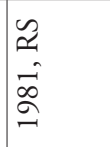 & $\begin{array}{l}N \\
\mathcal{N} \\
\tilde{N} \\
\tilde{N}\end{array}$ & $\begin{array}{l}\approx \\
\approx \\
\approx \\
\approx\end{array}$ \\
\hline 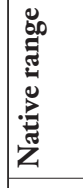 & 幽 & 䈉 & 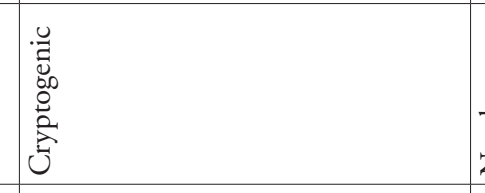 & 党 & 志莺 & 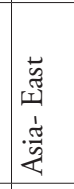 & 䋨 \\
\hline 离 & 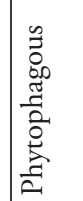 & 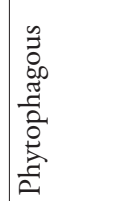 & 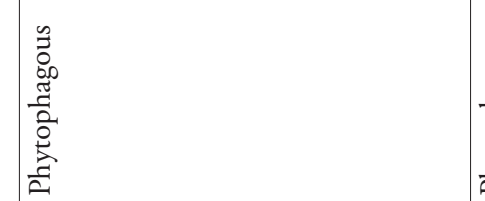 & 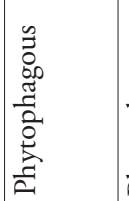 & 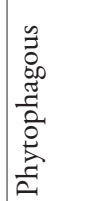 & 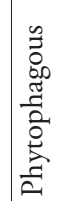 & 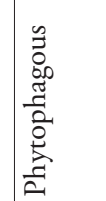 \\
\hline 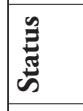 & u & $\ll$ & u & $\ll$ & $\varangle$ & $\varangle$ & $\varangle$ \\
\hline 过 & 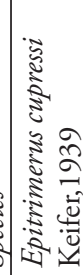 & $\frac{\sqrt{2}}{20}$ & 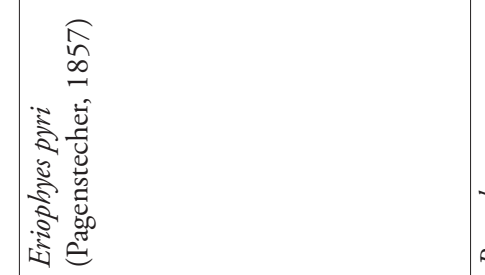 & 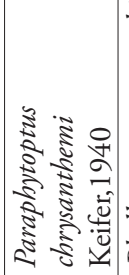 & 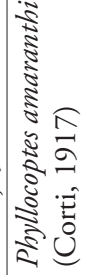 & 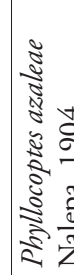 & 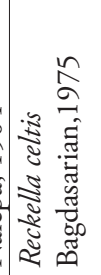 \\
\hline
\end{tabular}




\begin{tabular}{|c|c|c|c|c|c|c|c|c|}
\hline & 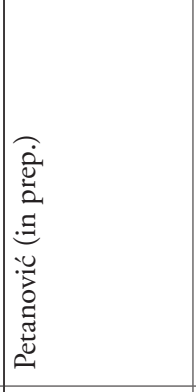 & 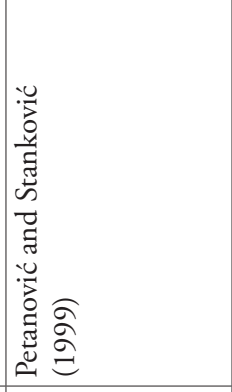 & 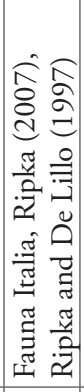 & 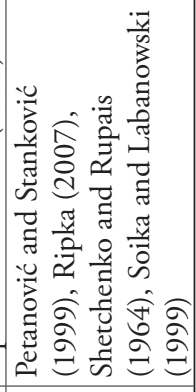 & 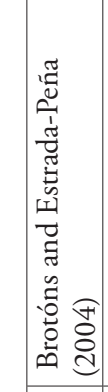 & 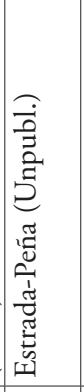 & & 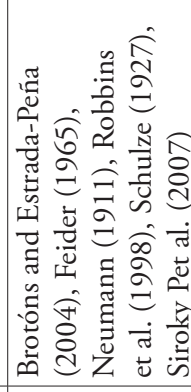 \\
\hline 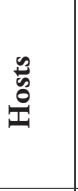 & 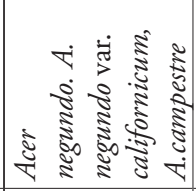 & 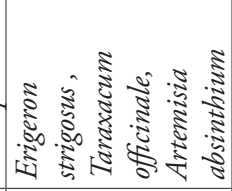 & 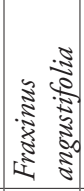 & 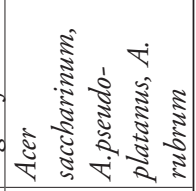 & 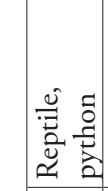 & 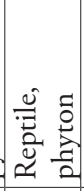 & 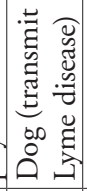 & 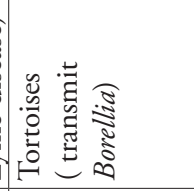 \\
\hline 苞 & $\begin{array}{l}\vec{\Downarrow} \\
\dot{x} \\
\overline{\bar{x}}\end{array}$ & $\begin{array}{l}\stackrel{\Im}{I} \\
\stackrel{5}{\sigma}\end{array}$ & 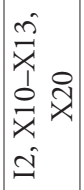 & صa & 디 & 디 & $\cup$ & $\neg$ \\
\hline 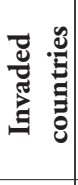 & 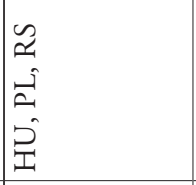 & $\approx$ & 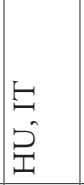 & 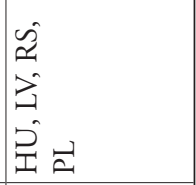 & 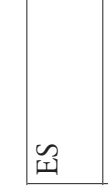 & 点 & 殅 & 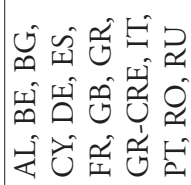 \\
\hline 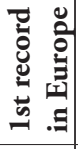 & $\begin{array}{l}\approx \\
\approx \\
\approx\end{array}$ & $\begin{array}{l}\mathscr{2} \\
2 \\
\stackrel{\infty}{\approx}\end{array}$ & $\begin{array}{l}\models \\
\infty \\
\infty \\
2 \\
\beth\end{array}$ & $\begin{array}{l}\lambda \\
\hat{n} \\
\approx\end{array}$ & 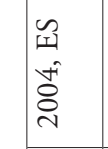 & 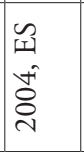 & $\begin{array}{l}\ddot{y} \\
\text { n: }\end{array}$ & 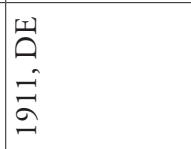 \\
\hline 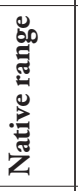 & 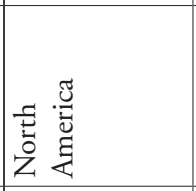 & 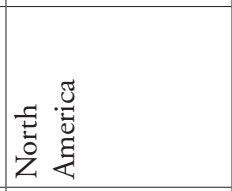 & 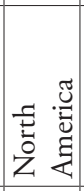 & 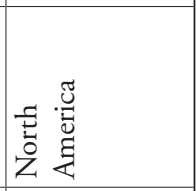 & 递 & 峞 & 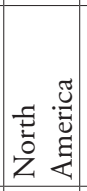 & 递 \\
\hline 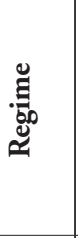 & 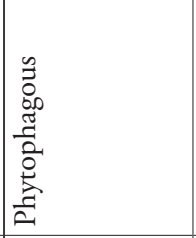 & 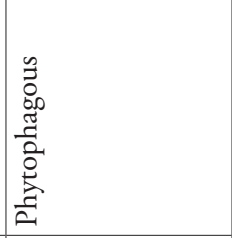 & 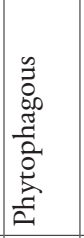 & 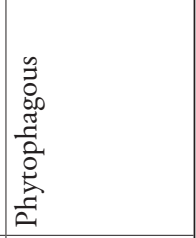 & 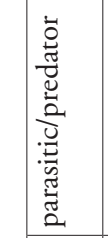 & 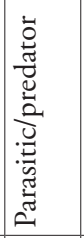 & 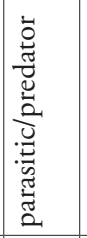 & 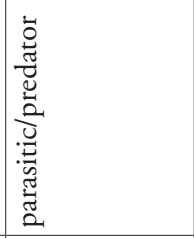 \\
\hline 总 & $\varangle$ & $\ll$ & $\ll$ & $\ll$ & $\ll$ & $\varangle$ & $\ll$ & $\varangle$ \\
\hline 包. & 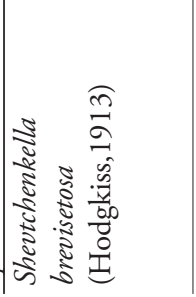 & 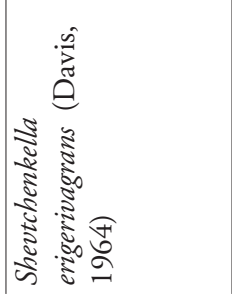 & 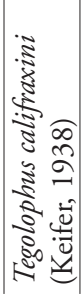 & 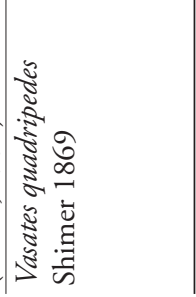 & 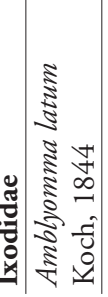 & 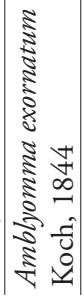 & 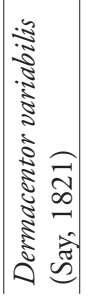 & 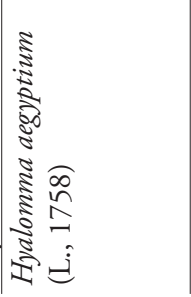 \\
\hline
\end{tabular}




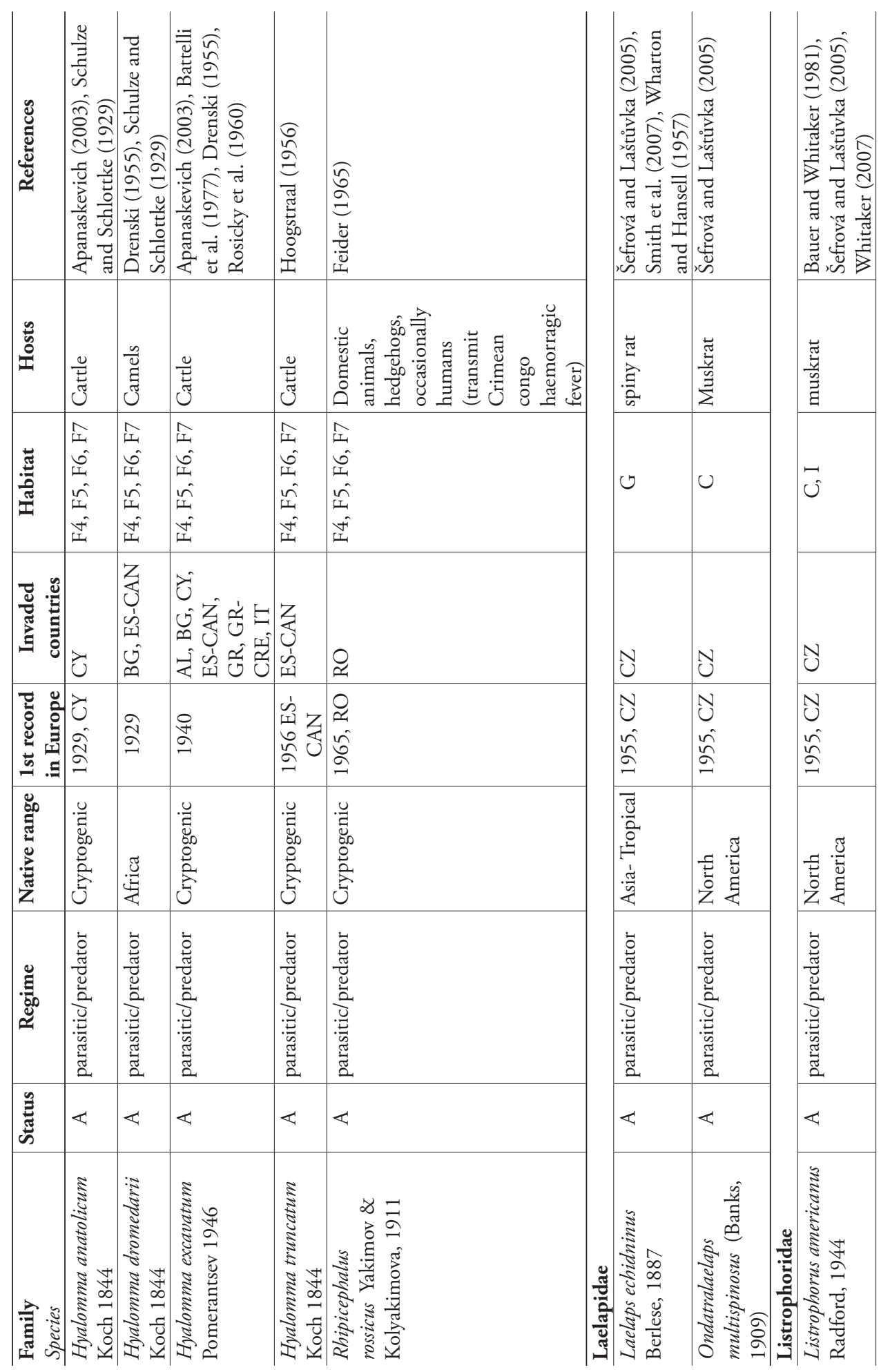




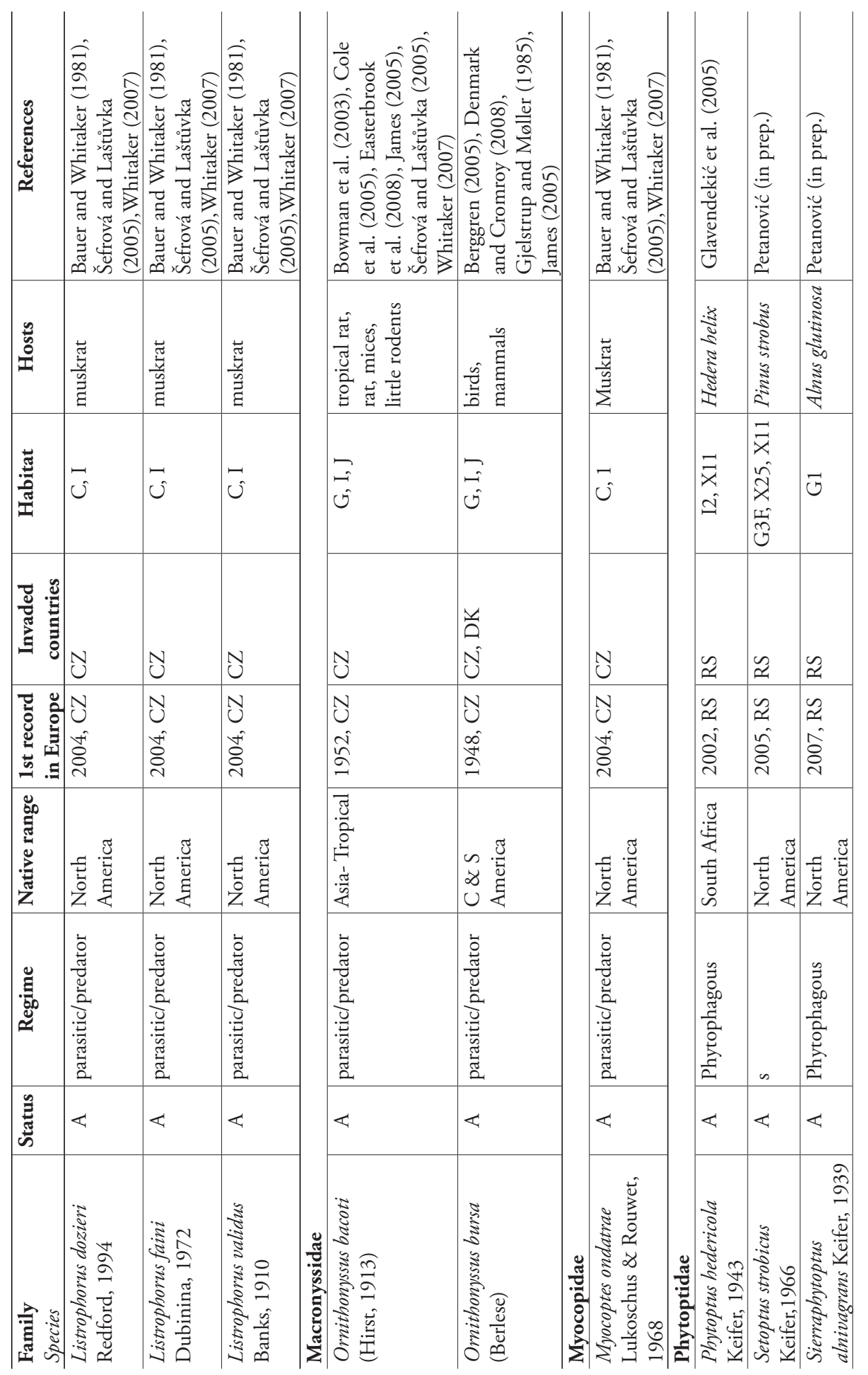




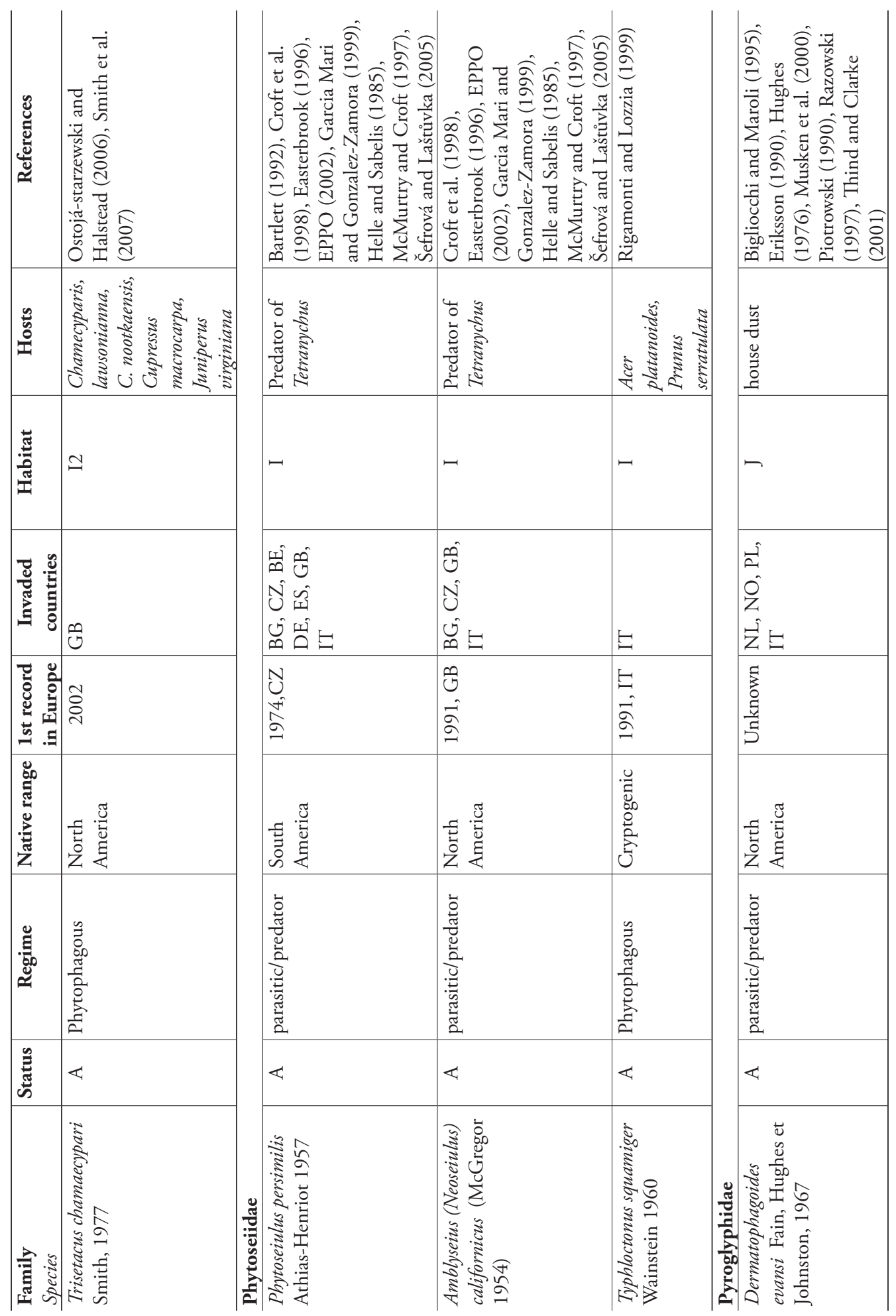




\begin{tabular}{|c|c|c|c|c|c|c|c|}
\hline 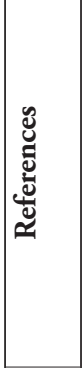 & 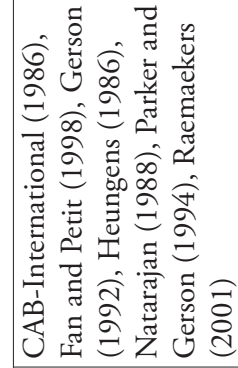 & & 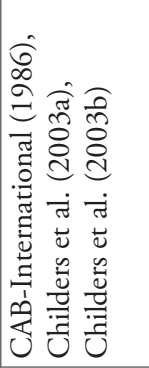 & 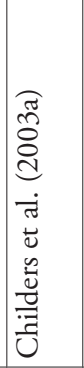 & 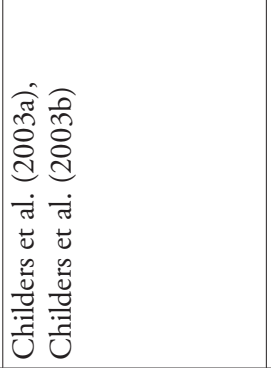 & 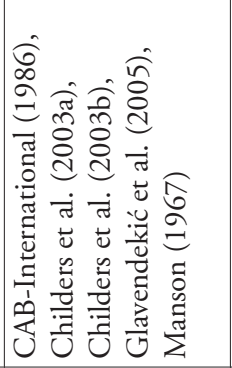 & 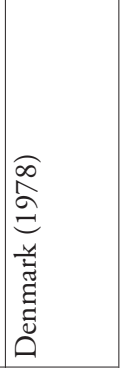 \\
\hline $\begin{array}{l}\stackrel{0}{0} \\
\stackrel{0}{I} \\
\text { I }\end{array}$ & 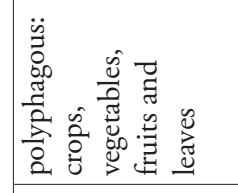 & & 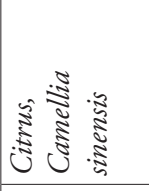 & 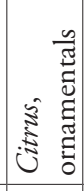 & 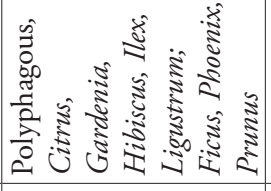 & 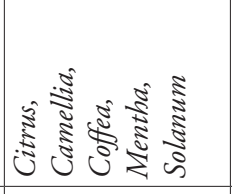 & 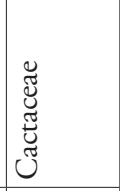 \\
\hline 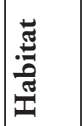 & - & & $\frac{8}{\stackrel{8}{\Xi}}$ & $\stackrel{8}{\stackrel{0}{\varrho}}$ & 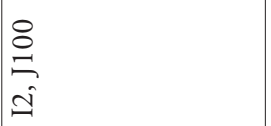 & $\simeq$ & $\stackrel{8}{\varrho}$ \\
\hline 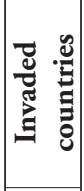 & 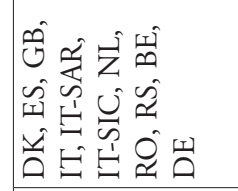 & & 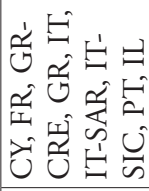 & 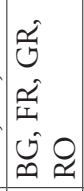 & 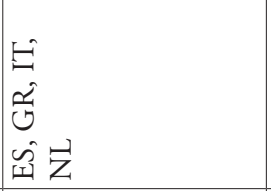 & 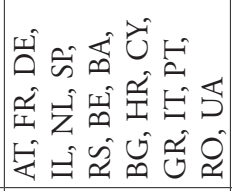 & 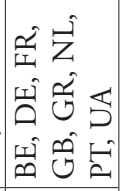 \\
\hline 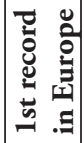 & $\begin{array}{l}\approx \\
\approx \\
\vdots \\
=\end{array}$ & & $\begin{array}{l}\infty \\
\stackrel{\infty}{\beth} \\
\end{array}$ & 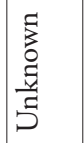 & $\begin{array}{l}\infty \\
\check{2} \\
\models \\
\models\end{array}$ & $\begin{array}{l}\infty \\
\infty \\
\cong \\
= \\
=\end{array}$ & 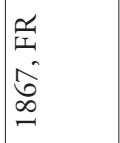 \\
\hline 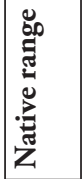 & 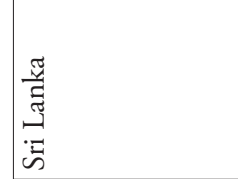 & & 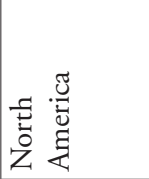 & 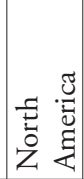 & 플 & 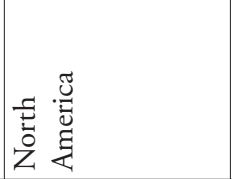 & 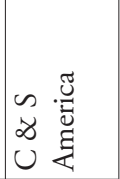 \\
\hline 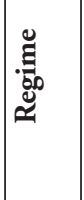 & 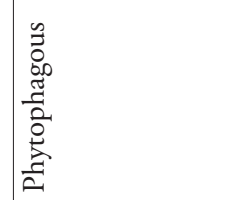 & & 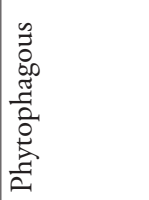 & 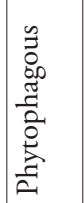 & 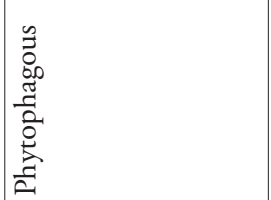 & 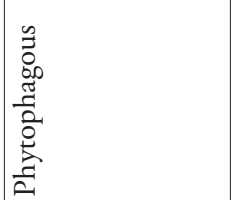 & 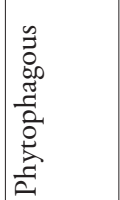 \\
\hline 䔍 & $\ll$ & & $\ll$ & $\ll$ & $\ll$ & $\ll$ & $\ll$ \\
\hline 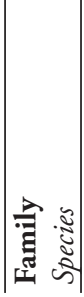 & 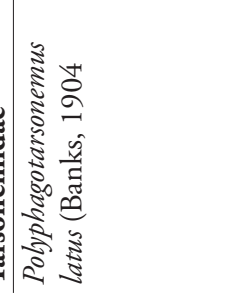 & & 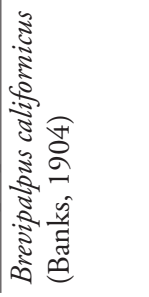 & 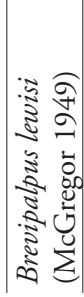 & 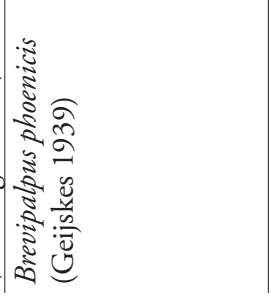 & 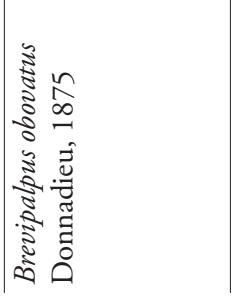 & 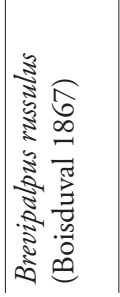 \\
\hline
\end{tabular}




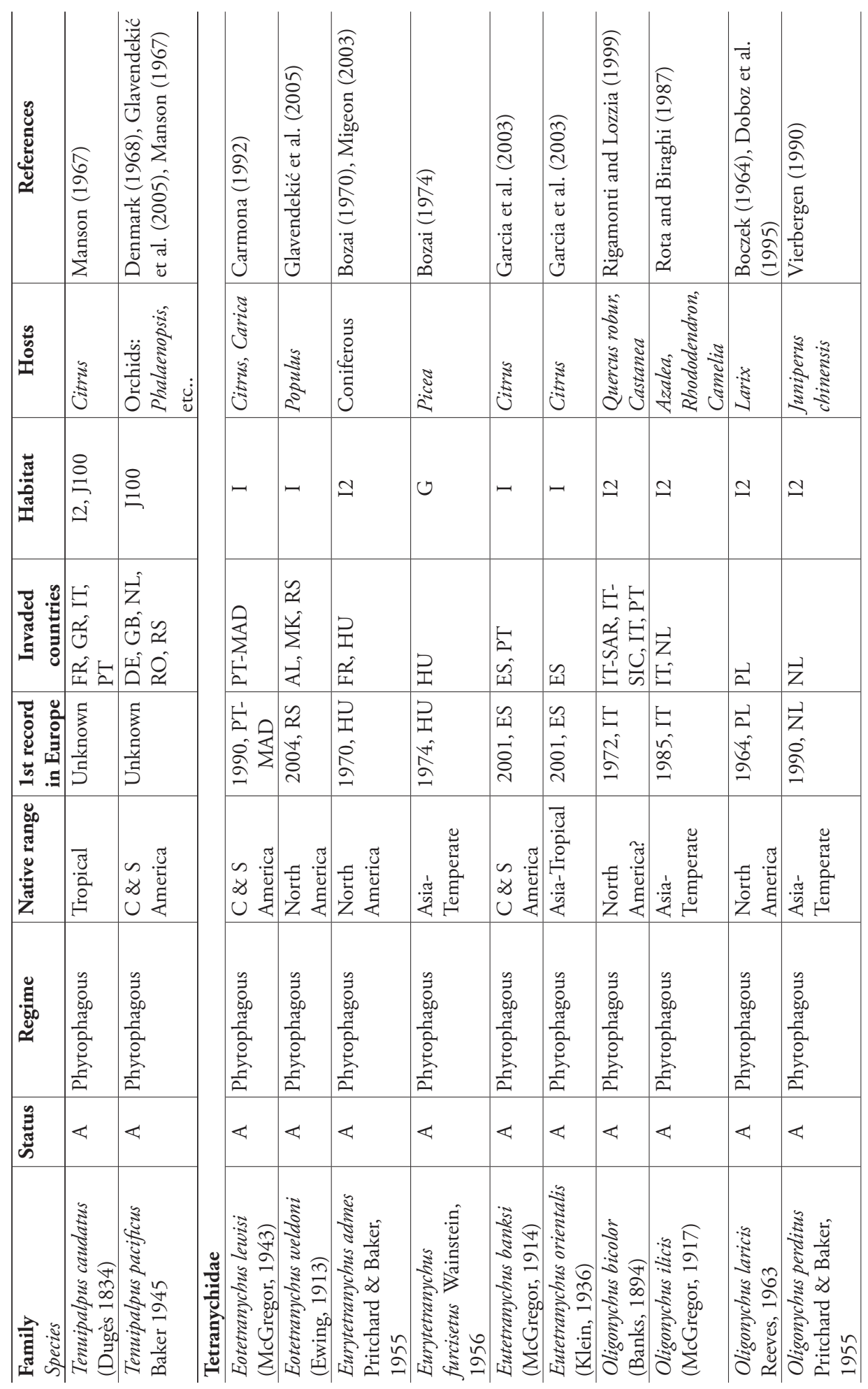




\begin{tabular}{|c|c|c|c|c|c|c|c|}
\hline & 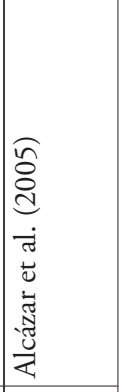 & 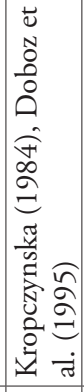 & 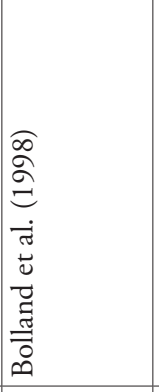 & 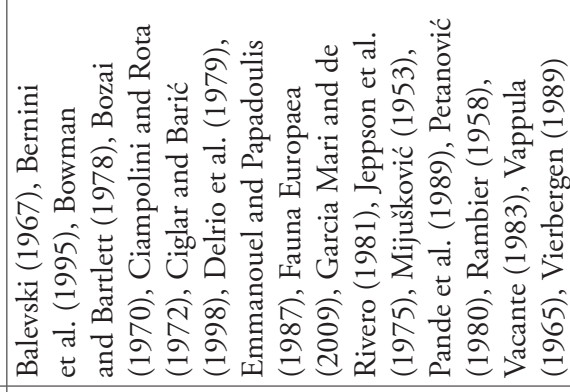 & 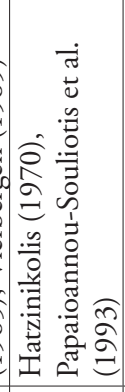 & 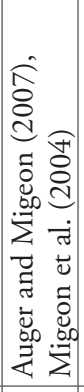 & 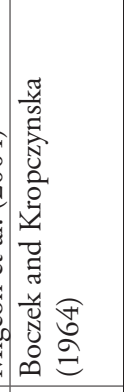 \\
\hline 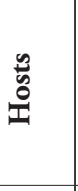 & 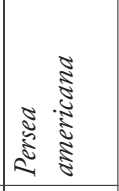 & 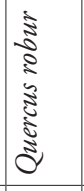 & 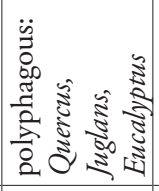 & $\frac{0}{3}$ & 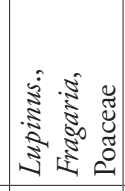 & 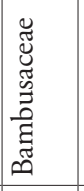 & 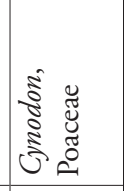 \\
\hline 莺 & $=$ & $\cup$ & $\simeq$ & $\begin{array}{l}\cong \\
\cong\end{array}$ & • & 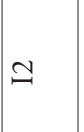 & $\neg$ \\
\hline 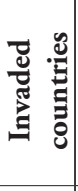 & is & $\vec{\Xi}$ & 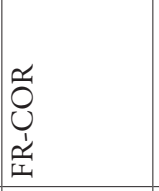 & 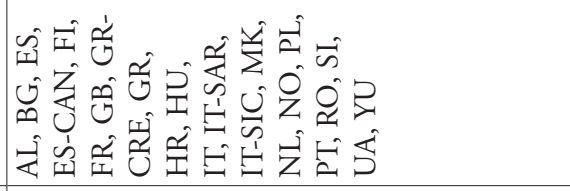 & $\stackrel{\mathscr{0}}{0}$ & 寽 & $\Xi$ \\
\hline 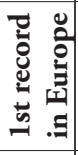 & 离 & 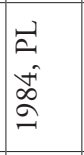 & 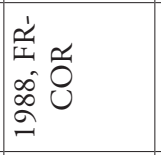 & 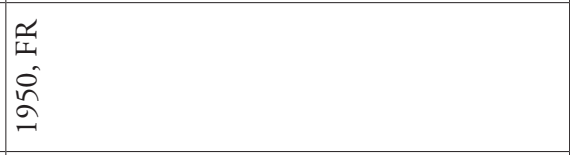 & \begin{tabular}{l}
\multicolumn{1}{c}{} \\
0 \\
$\infty$ \\
0 \\
$\varrho$
\end{tabular} & 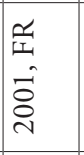 & 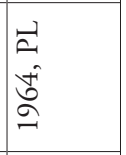 \\
\hline 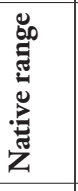 & 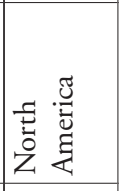 & 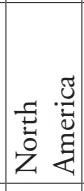 & 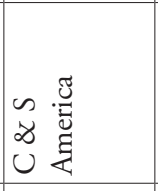 & $\frac{.5}{\frac{3}{2}}$ & 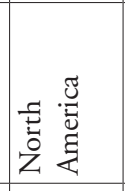 & 䇋 & 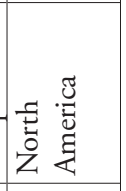 \\
\hline$\underset{\mathscr{E}}{\mathscr{G}}$ & 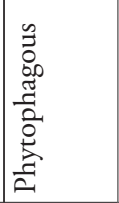 & 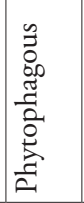 & 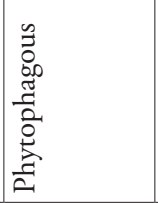 & 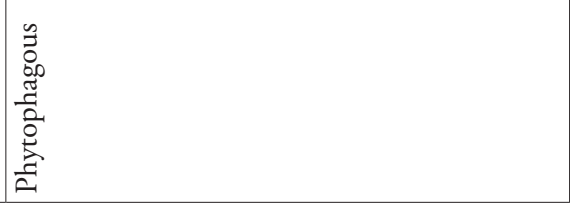 & 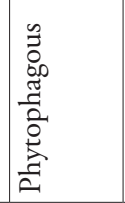 & 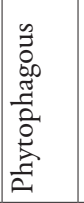 & 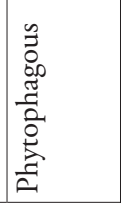 \\
\hline$\stackrel{\mathscr{E}}{\tilde{J}}$ & $\ll$ & $\ll$ & $\varangle$ & $<$ & $\ll$ & $\ll$ & $\varangle$ \\
\hline 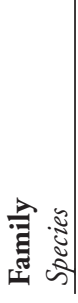 & 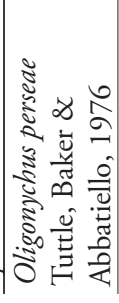 & 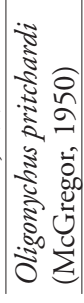 & 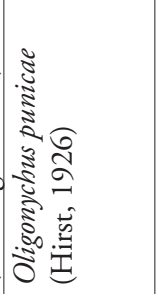 & 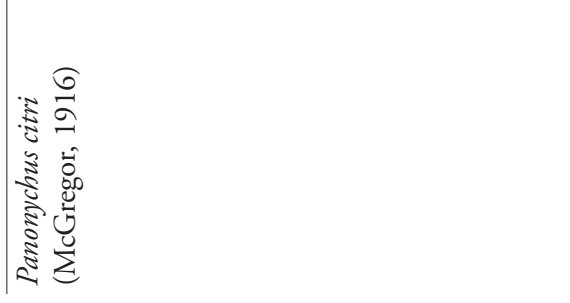 & 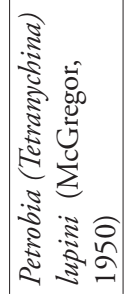 & 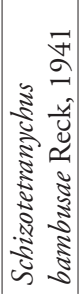 & 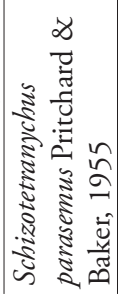 \\
\hline
\end{tabular}




\begin{tabular}{|c|c|c|c|c|c|c|c|c|c|}
\hline 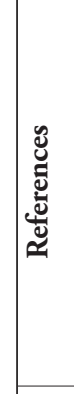 & 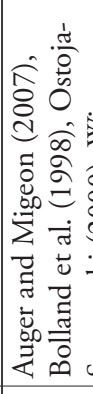 & 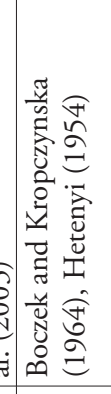 & 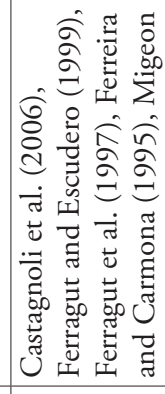 & 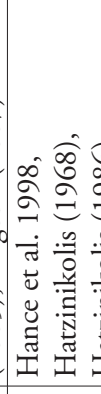 & 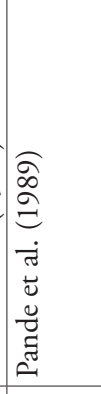 & 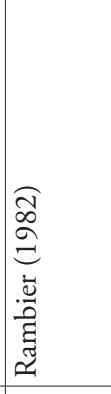 & & 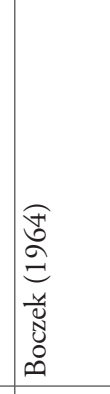 & \\
\hline & 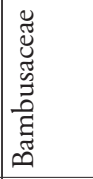 & 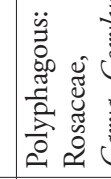 & "ू. & 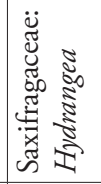 & 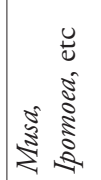 & & $\begin{array}{l}0 \\
0 \\
0\end{array}$ & & 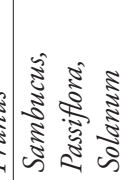 \\
\hline 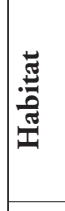 & 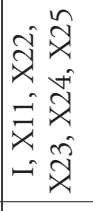 & $\approx$ & 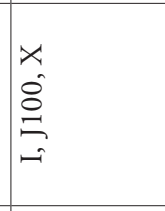 & $\stackrel{8}{\varrho}$ & $\neg$ & - & - & - & - \\
\hline & & 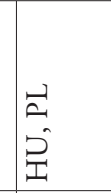 & 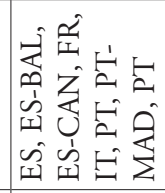 & 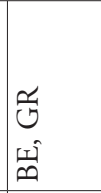 & 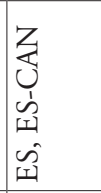 & 䍃 & $\begin{array}{l}z \\
\text { z } \\
\text { w } \\
\text { m }\end{array}$ & $\vec{\Xi}$ & 윙 \\
\hline 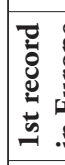 & 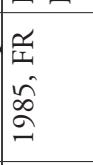 & 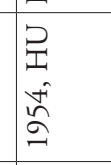 & $\begin{array}{l}\overrightarrow{\vec{a}} \\
\overrightarrow{\vec{D}} \\
\overrightarrow{\vec{D}}\end{array}$ & 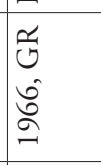 & 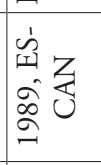 & 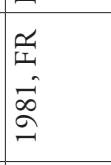 & 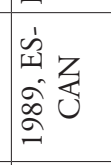 & \begin{tabular}{l}
$\vec{a}$ \\
\multirow{2}{*}{} \\
$\stackrel{2}{0}$
\end{tabular} & 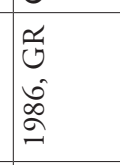 \\
\hline 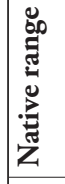 & 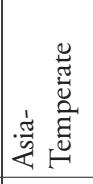 & 吾莺 & 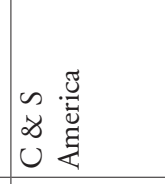 & 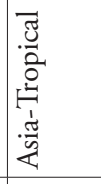 & 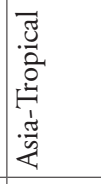 & 吾蒫 & 胥 & 吾莺 & 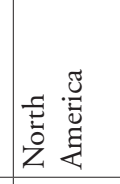 \\
\hline 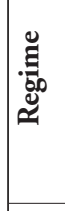 & 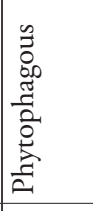 & 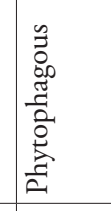 & 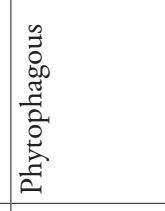 & 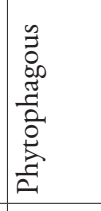 & 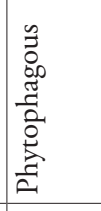 & 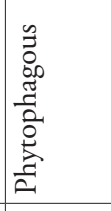 & 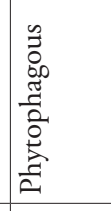 & 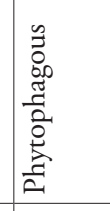 & 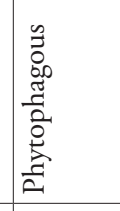 \\
\hline 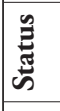 & $\varangle$ & $\varangle$ & $\varangle$ & $\varangle$ & $\varangle$ & $\varangle$ & $\varangle$ & $\varangle$ & $\varangle$ \\
\hline & 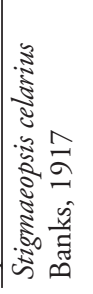 & 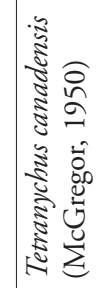 & 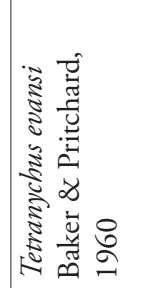 & 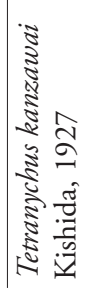 & 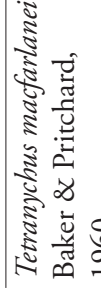 & 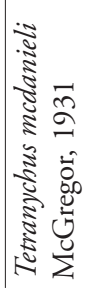 & 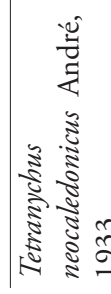 & 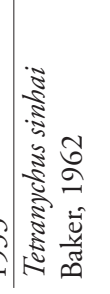 & 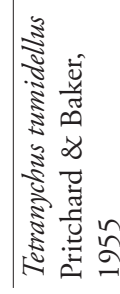 \\
\hline
\end{tabular}




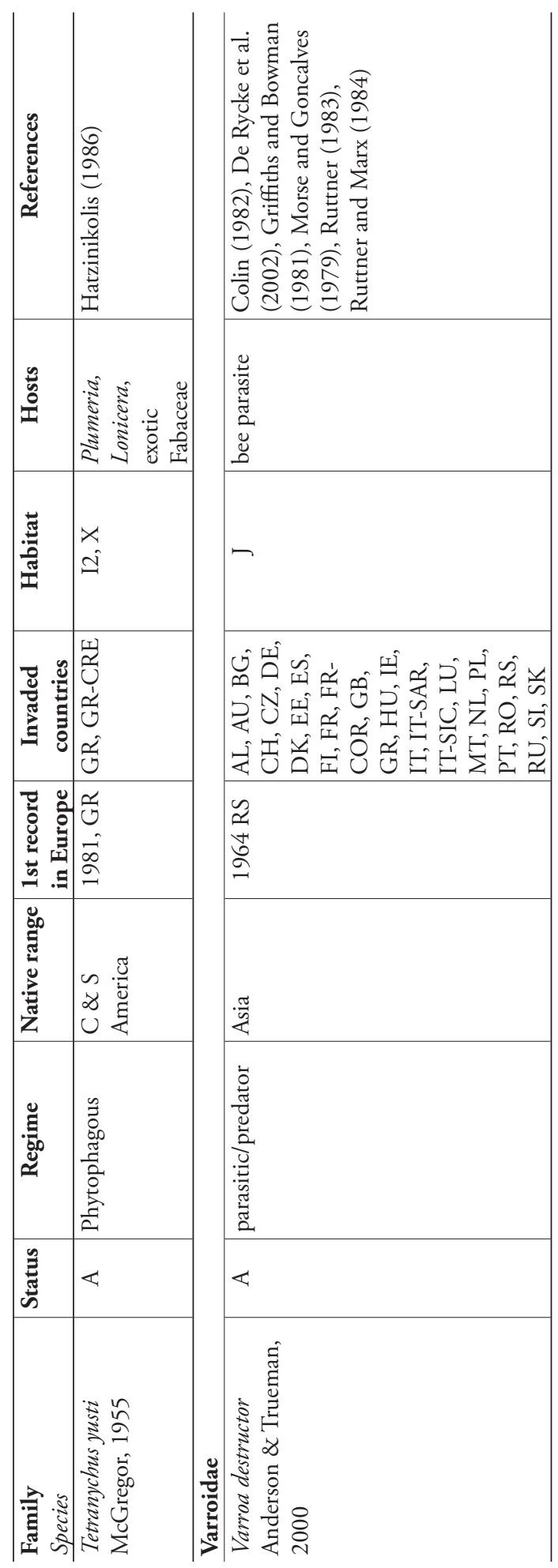




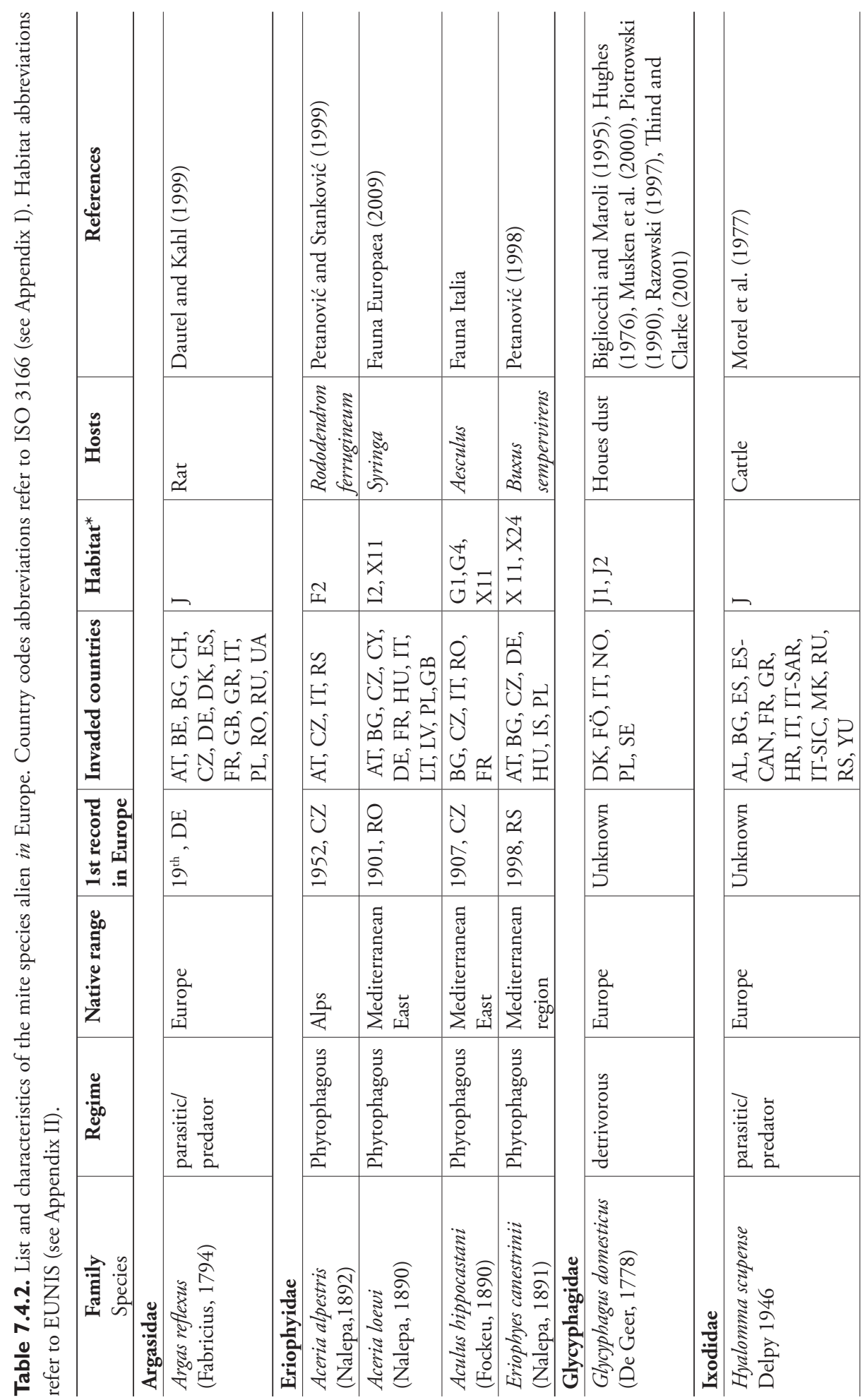




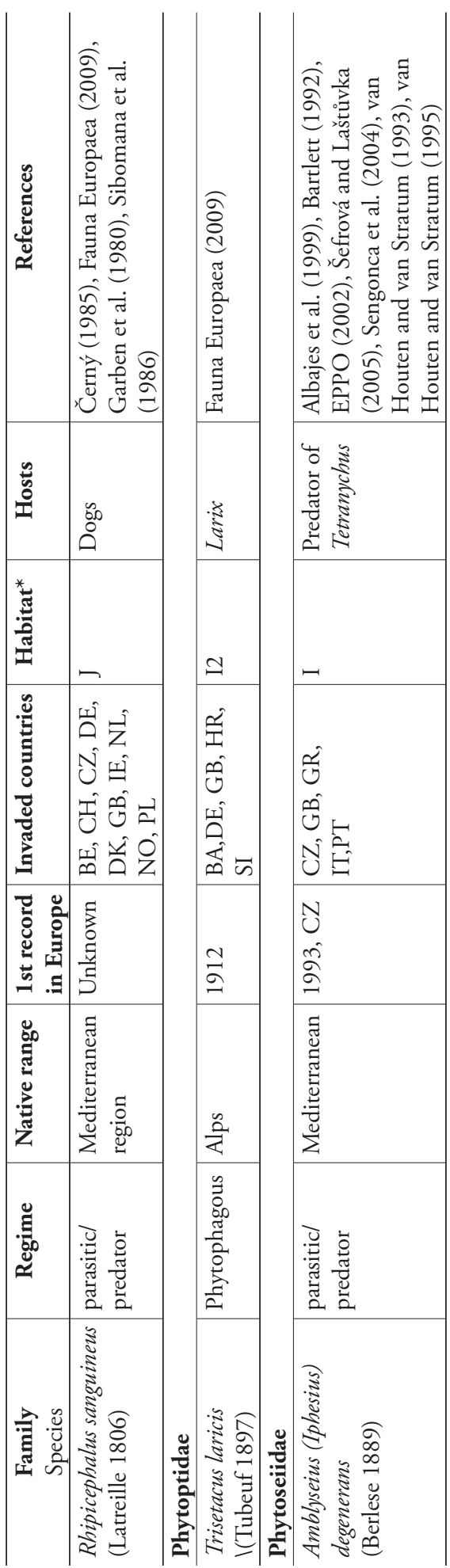

